\title{
An Assessment of LEED Certification's Impact on Net Rental Rates for Commercial Office Space in Toronto, Ontario
}

Master of Science in Management - Faculty of Graduate and Post Doctoral Studies

Shawn Roy

Supervisors:

Prof. Tom Brzustowski, Telfer School of Management

Prof. Scott C. Ensign, Telfer School of Management

(C) Shawn Roy, Ottawa, Canada, 2011 


\section{Abstract}

With issues such as energy crises, climate change and environmental degradation becoming evermore prevalent on national and international levels, industrialized societies are beginning to take heed of the impact they are having on the natural environment and we are beginning to see movements towards socially ${ }^{1}$ and environmentally responsible decision-making. With the impact that buildings have on the environment, it is important to understand what barriers are preventing or slowing investment in socially and environmentally responsible property.

The present study was conducted to determine whether LEED $^{2}$ certification has a significant impact on the market value ${ }^{3}$ of office buildings in Toronto, Ontario - value determined by the average net asking rent ${ }^{4}$ for each building. For some 68 subject and control buildings, we matched information on the net asking rent for 16 LEED certified (subject) buildings to 52 otherwise comparable properties (control buildings). Using ordinary least squares (OLS) analysis, we looked to find what relationship exists between net asking rent and the LEED label. Controlling for other variables historically shown to have an impact on property value, we expected the results of this study to determine whether there is a business case for LEED certification in the downtown Toronto office market.

The results of the study have shown that LEED certification has had no impact on the market value of the sample of office buildings in Toronto. This is a surprising result, given the growth in the number of LEED buildings in Canada, but interviews with three senior executives in the industry have helped to provide insight into this trend. It seems that with time LEED will likely have an impact in this market, but it hasn't arrived yet.

\footnotetext{
${ }^{1}$ General sustainability criteria include corporate governance, financial robustness, environmental management and performance, human rights, supply chain management, risk and crisis management, and labour practices (Pivo, 2005).

${ }^{2}$ Leadership in Energy and Environmental Design (LEED) is a third-party (Canadian or U.S. Green Building Council) certification program that has become the benchmark for the design, construction and operation of high performance green buildings in North America.

${ }^{3}$ The International Valuation Standards Committee defines Market Value as, "the estimated amount for which a property should exchange on the date of valuation between a willing buyer and a willing seller in an arms' length transaction after proper marketing wherein the parties had each acted knowledgably, prudently and without compulsion"(International Valuation Standards, 2007).

${ }^{4}$ The Net Asking Rate is the annual amount a landlord charges a lessee over and above the "additional rent". Additional Rent is the amount the landlord will charge to cover the costs associated with running a building, which may include property taxes, common area maintenance and any other expenses the landlord charges that are associated with the operating of the property.
} 


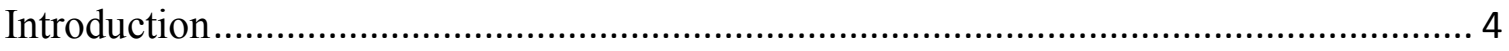

Background and Motivation ...................................................................

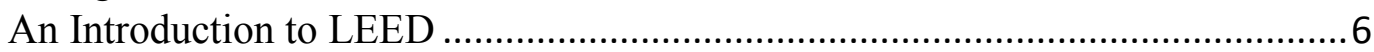

Research Questions and Objectives............................................................

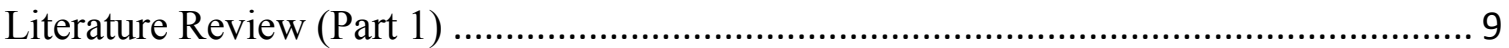

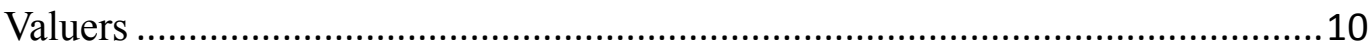

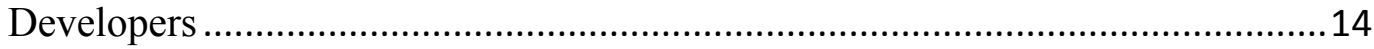

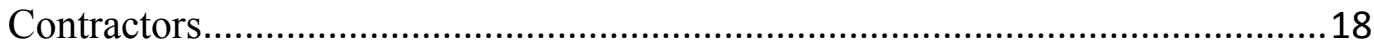

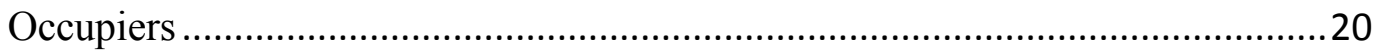

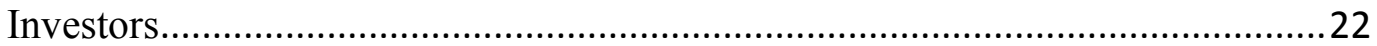

Studies of Responsible Property Initiatives .........................................................24

Literature Review (Part 2) ..................................................................................... 27

Research Design and Methodology ......................................................................... 30

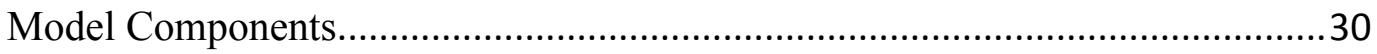

Data Collection …………………………………………………………………... 31

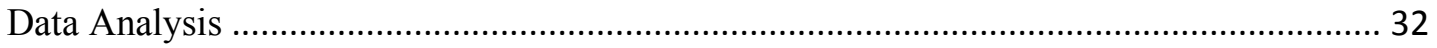

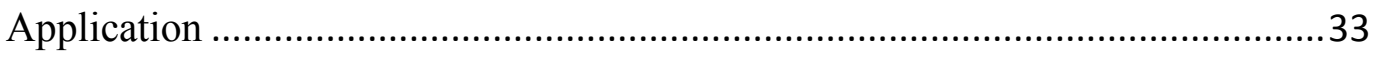

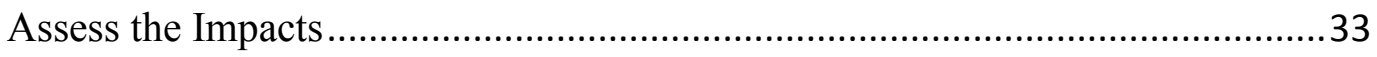

Analysis and Results ........................................................................................... 34

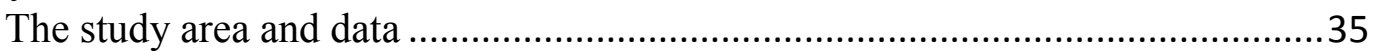

The study area: Toronto, Ontario .................................................................................. 35

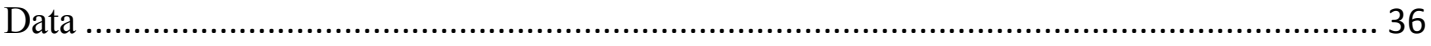

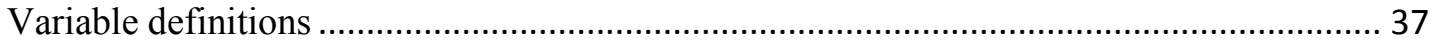

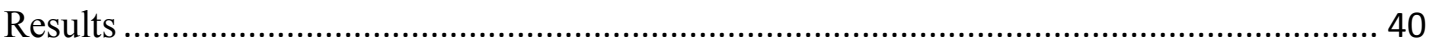

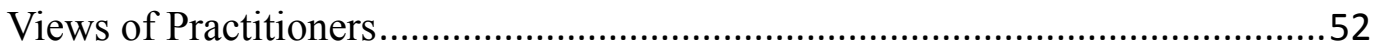

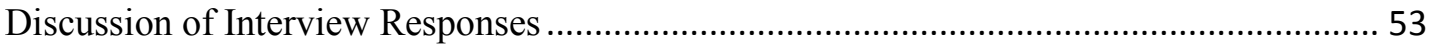

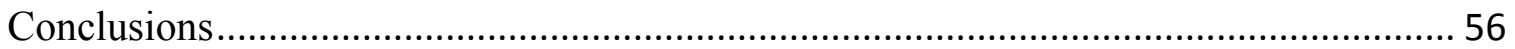

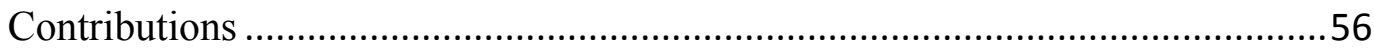

Implications for practitioners........................................................................5

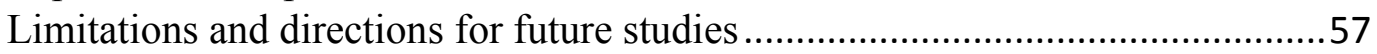

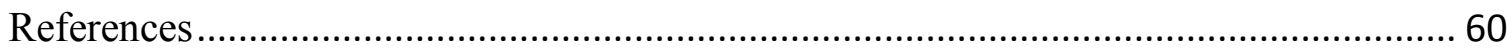

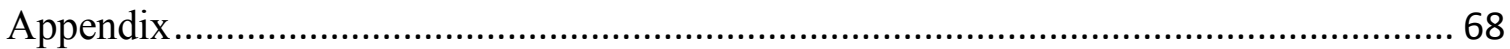

Appendix A: Membership Growth in Canadian Green Building Council ...68

Appendix B: Membership Growth in U.S. Green Building Council .............69

Appendix C: "The Vicious Circle of Blame"..................................................69

Appendix D: Transcription of Interviews ..................................................... 


\section{Introduction}

\section{Background and Motivation}

The movement towards green building has gained momentum from a number of energy crises, environmental disasters, global pollution concerns and the environmental movements that have taken place in recent history. These trends and events have led to a number of publications and the development of several councils, task forces and associations formed by industry, governments and non-government organizations.

One indicator of the effect this movement has been having on the interest in green buildings ${ }^{5}$ is the growth in membership in the green building councils in $\mathrm{Canada}^{6}$ and the United States. ${ }^{7}$ Although the figures indicate an increased interest in the green and sustainable property movement, the reality is that up until 2005 Canada had seen less than 200 buildings become registered for LEED(Lucuik, 2005). There are a number of stakeholders involved in Canada's slow rate of adoption of green/sustainable building standards, and the specific issues faced by these stakeholders and the relationships between these groups has been the focus of many recent studies.

The cycle inhibiting the production of sustainable buildings has been described by many (Keeping, 2000; Rapson, 2007; Myers, 2008; Lorenz, 2008) as “The Vicious Circle

\footnotetext{
${ }^{5} \mathrm{~A}$ Green Building is a property "that uses resources efficiently, reduces waste and provides superior indoor air and other qualities." A Green Value is the value obtainable by a green building fover and above\} the market compared to a non-green peer group. Therefore the Green Value is an integral part of the overall market value. Both parts can only theoretically be separated (RICS, 2005).

${ }^{6}$ See Appendix A for a chart depicting membership growth in the Canadian Green Building Council.

${ }^{7}$ See Appendix B for a chart depicting membership growth in the U.S. Green Building Council.
} 
of Blame". ${ }^{8}$ A number of studies have been performed in assessment of the factors inhibiting the adoption of social and environmental initiatives in the commercial real estate industry. These studies investigate the factors inhibiting adoption by:

- Valuation professionals (Guertler, 2005; Millington, 2000; Warren-Meyers, 2009; Reed, 2009; Lorenz, 2008; Robinson, 2005);

- Investors (Hagart, 2008; Pivo, 2008; Eichholtz et al., 2009; Miller, 2008; Roper, 2006; Loftness, 2005; Sayce, 2007; Pivo, 2005; Parnell, 2005; Kats, 2003);

- Developers (Pivo, 2009, Eichholtz, 2009, Lippiatt, 1999; Robert, 2002;

Matthiessen, 2004; Kats, 2003);

- Contractors (Matar, 2008; Lam, 2007; Lam 2010; Matar, 2004; Matar, 2007; Du Plessis, 2002; Reed, 2003; Landman, 1999; Pearce, 2002; Scheuer, 2002; Vanegas, 2000); and, - Occupiers (Broughton, 2006; Ellison, 2006; Fisk, 2000; Morton, 2002; Lucuik et al., 2005; Eichholtz et al., 2009).

However, the vast majority of these studies only provide anecdotal evidence in the form of engineering estimates, case studies and surveys of opinion; most of which have been performed on markets outside of Canada (particularly the US, UK, and Australia). It is therefore a motivation for this research to contribute to the literature by investigating the adoption of LEED in Canadian markets, specifically in Toronto, Ontario.

\footnotetext{
${ }^{8}$ See Appendix C for a depiction of the "Vicious Circle of Blame."
} 


\section{An Introduction to LEED}

LEED is a third-party certification program and an internationally accepted benchmark for the design, construction and operation of high performance green buildings. It provides building owners and operators the tools they need to have an immediate and measurable impact on their buildings' performance. It was designed by the U.S. Green Building Council to encourage and accelerate global adoption of sustainable green building and development practices through the creation and implementation of universally understood and accepted tools and performance criteria. These performance criteria are evaluated through a suite of rating systems that recognize projects that implement strategies for better environmental and health performance.

The Canadian rating systems are an adaptation of the US Green Building Council's (USGBC) LEED Green Building Rating System, tailored specifically for Canadian climates, construction practices and regulations. The rating systems are adapted to the Canadian market through an inclusive process that engages stakeholders and experts representing the various sectors of the Canadian industry.

The Green Building Certification Institute (GBCI) administers LEED certification for all commercial and institutional projects registered under any LEED Rating System. The Canadian Green Building Council (CaGBC) administers the development and ongoing improvement of the LEED rating systems. $\mathrm{CaGBC}$ is also the primary source for LEED and green building education and resources for project teams, such as reference guides, rating system addenda, workshops, online trainings and other tools to help you achieve success on your LEED project. 
Building types that are eligible for certification include - but are not limited to offices, retail and service establishments, institutional buildings (e.g., libraries, schools, museums and religious institutions), hotels and residential buildings of four or more habitable stories. In addition, the $\mathrm{CaGBC}$ has developed separate rating systems that take into the specific needs of: new construction, core and shell, commercial interiors, existing buildings, homes, and neighbourhoods. For any project that falls under one of these categories, LEED promotes a whole-building approach to sustainability by recognizing performance in five key areas of human and environmental health:

- sustainable site development

- water efficiency

- energy efficiency

- materials selection

- indoor environmental quality

Credits and Prerequisites are organized into these five categories. An additional category, focusing on innovation, addresses sustainable building expertise, exemplary performance, and design (or operational) measures not covered under these five environmental categories. Projects are rated on a 100-point scale, and credits are weighted to reflect their potential environmental impacts. Additionally, 10 bonus credits are available, four of which address regionally specific environmental issues. A project must satisfy all prerequisites and earn a minimum number of points to be certified, and level of certification is based on the total point score achieved, with four possible levels 
of certification (certified, silver, gold and platinum). (Canadian Green Building Council, 2011; U.S. Green Building Council, 2011)

Despite the development of several versions of LEED designed to account for the challenges faced by those looking to build and retrofit buildings in Canada, the rate of adoption has been slow when compared to adoption of LEED in the U.S.. In order for LEED to be widely adopted in Canada, compelling empirical evidence of the benefits it offers needs to be provided in order for stakeholders to be motivated to make decisions that will lessen the negative impact that buildings are having on the natural environment. ${ }^{9}$

\section{Research Questions and Objectives}

As there are a number of variables that contribute to building value, it is important to take these factors into account when trying to determine what impact, over and above all other factors, LEED certification has on office rents. The present research employs OLS to assess the factors affecting building net asking rates. The objective is to effectively separate LEED's contribution to net asking rent from that contributed by all other variables.

Thus, the research question is: Does LEED certification matter in downtown Toronto, Ontario's office rental market yet?

In response to this question, the objectives of this research are to:

\footnotetext{
${ }^{9}$ The Natural Environment, encompasses all living and non-living things occurring naturally on Earth or some region thereof.
} 
1) Identify the key stakeholders involved in the market adoption of socially responsible property initiatives (SRPI) such as LEED.

2) Identify the factors inhibiting and motivating market adoption of SRPI by those stakeholders shown to be a catalyst to adoption by the rest of the market.

3) Analyze the impact of LEED labeling on those factors affecting market adoption of SRPI by key stakeholders.

The answers to these research questions will allow for the identification of key stakeholder groups, factors influencing their adoption of LEED certification, and climate for market adoption of LEED certification in Toronto, Ontario. Although the development of the models will be general in nature, for the purpose of this study, the research will be specific to downtown Toronto, Ontario. Therefore, it is important to note that although the model specifications can be used in future studies, the results of this study are specific to downtown Toronto, Ontario, and cannot be generalized to other markets.

Research Objective 1 - Identify the key stakeholders involved in the market adoption of socially responsible property initiatives (SRPI) such as LEED.

\section{Literature Review (Part 1)}

The review of literature provides an examination of the issues faced by key stakeholder groups in their adoption of LEED standards. Included in this examination are issues faced by (2.1) Valuers, (2.2) Investors, (2.3) Developers, (2.4) Contractors and (2.5) Occupiers. 


\section{Valuers}

As the stakeholders responsible for assessing a property's market value, the willingness and ability of valuers to attribute a portion of a building's value to its green attributes will affect the determination of its worth to other stakeholders and ultimately their willingness to adopt green standards. The link between valuation and action taken by other stakeholders has been shown in past research of building energy performance, which has shown that unless valuation professionals appreciate the importance of low energy offices, the likelihood of the Energy Performance in Buildings Directive having any impact in a reasonable time is small (Guertler, 2005). That is to say, if valuation professionals do not incorporate building energy performance into their assessments of property value, market adoption of energy saving technology will be slow and impact that building energy performance directives have on the environment will be lessened.

The determination that specific building characteristics contribute to property value plays an important role in the decision of investors and developers as to the degree to which they will pursue specific building attributes. Traditionally, the main issues that are taken into account when determining whether a building is of 'investment quality' are location, condition, design, size and quality of the floor space, amenities and service, adaptability to different tenant's requirements, and infrastructure (transport and communications) (Millington, 2000; Guertler, 2005). In assessing the value contribution of these individual attributes valuers search for and analyze comparable market data. 
Finding comparable data is a basic fundamental of property valuation - not just when applying the comparison approach ${ }^{10}-$ and analyzing this data to derive input figures which could be used within the valuation process. The essential rule to ensure that the outcome is correct is therefore: to compare apples with apples! Comparables must have the same building characteristics in terms of location, technical equipment, condition, and tenant profile among other attributes, and also with respect to greenfeatures (e.g. energy efficiency level). With the introduction of yet another aspect which needs to be comparable, the assessment of the subject and comparable properties will become more complex (Warren-Myers, 2009).

In addition to the complexity of including green-features into the characteristics to be evaluated in the property valuation process, there are also a number of issues associated with the tools used to rate a building's 'greenness'. Within the rating tools, particularly design oriented tools like LEED, Green Star and BREEAM where certification is assessed over a number of environmental categories, the ability to compare properties is inherently difficult; as the achievement of certification can be accomplished through various pathways and often these are not openly addressed or advertised in the marketplace. Therefore the lack of transparency in how buildings achieve their certification levels prevents valuers and appraisers from being able to compare properties on a 'like for like' basis as required by valuation statute (WarrenMyers, 2009).

\footnotetext{
${ }^{10}$ The comparison approach adjusts the prices of the comparable transactions according to the presence and degree of characteristics which influence value.
} 
Along with the difficulty in comparing 'apples to apples' when taking green attributes into consideration during the valuation process, the following barriers to acceptance of sustainability considerations in valuation must also be addressed (Reed, 2009):

- Lack of knowledge about the effects on value

- Inability of valuation approaches to incorporate sustainability

- Quantifying the intangible aspects of "greenness" in the valuation

- Point of difference (marketing)

- Government legislation (regulations as well as incentives)

- Addressing long-term obsolescence

In addition to these barriers, another major issue furthering the reluctance of valuers to incorporate socially responsible property characteristics in their valuation is who derives the benefit associated with these characteristics. Traditionally, market valuation implies that only direct monetary benefits or reductions in property-specific risks that are realized by the owner or user of the asset have to be taken into account within the valuation process. Indirect or non-monetary benefits that are realized by society or the environment are not to be considered (Lorenz, 2008).

There are a number of proposed developments to valuation seeking to overcome these barriers. Likely future development incorporating sustainability considerations into valuation include (Reed, 2009):

- Changing perception of sustainability

- Updated definition of market value

- Changing relationship between cost and value 
- Increased communication and information availability

- Undertaking explicit evaluations

Past studies of green building initiatives have used the energy savings associated with green design to determine the value associated with green design features, with the most influential of those being that conducted by Greg Kats in 2003. The problem with these determinations of the value of green design features is that energy use is a very small percentage of business costs, even though for some companies, the actual bill is a large amount in absolute terms. Very few organizations use whole-life costing to evaluate energy efficiency improvements, and the actual cost of energy in use can be low compared with the project management cost of improvement, possibly regardless of whether whole-life costing ${ }^{11}$ is applied (Guertler, 2005). In addition, energy, like other business related expenses, is tax deductible and the plant and equipment that use energy can be depreciated against taxable income, causing lenders of capital neglect environmental costs in their assessment frameworks (Robinson, 2005). If valuers, lenders, and investors are going to attribute value to green design features they are going to need better impartial evidence of the value generated by green features and related performance (Green value. green buildings, growing assets 2005). Gaining such evidence would allow green characteristics to be incorporated into property valuation and accelerate the adoption of green buildings.

\footnotetext{
${ }^{11}$ Whole Life Costing refers to evaluating the total cost of ownership over the life of an asset.
} 


\section{Developers}

In general, in socially responsible investing, few companies are eliminated or included in funds or indices because of the products they produce. Exceptions include guns and tobacco. But generally, companies that do a good job with social, environmental and governance issues regardless of their products are included. The focus is on how they do their business and produce their products, not on what products they produce. However, with real estate, companies or funds or trusts can be differentiated both in terms of how they produce their products and the types of products they produce (Pivo, 2005).

Both real estate developers and institutional investors are understandably uncertain about how far to go in implementing environmental investments, since the economic rationale for the development of sustainable buildings is based almost entirely on anecdotal evidence (Eichholtz, 2009). In addition, because buildings can be sources of environmental degradation during their construction, operation and demolition, it is difficult for developers to determine what the most cost-effective methods of greening their projects are. According to Lippiatt (1999), although environmental performance cannot be measured on a monetary scale it can be quantified using the evolving, multidisciplinary approach known as environmental life-cycle assessment. This method of assessment is also known as the cradle-to-grave approach as it takes into account the impact that the construction, operation and eventual demolition of a building will have on the environment. 
Before a building is developed, it is important to take into consideration not only the short-term operation of the building, but instead take a cradle to grave approach to planning project design and construction. It is not sufficient to undertake investments that approach compliance with the system conditions in the short term. A neglected principle is that the steps taken must also avoid dead ends in the future. This means that each investment should provide feasible stepping-stones, or "flexible platforms," to link to future investments in the same direction. This is particularly important when investments are large, and consequently tie up money and resources for extended periods of time (Robèrt, 2002).

The ability to design and construct new developments to be able to adapt to new standards is an important element in making investment in socially responsible property more feasible. Unfortunately, it is too late for existing buildings to benefit from this type of forethought, and as a result, retrofitting these properties to be more socially and environmentally responsible is often more difficult and costly than for new construction. Retrofitting involves both direct costs (the upfront capital cost of working on the building fabric or replacing heating, ventilation, and air conditioning (HVAC) equipment) and opportunity costs (the rent that landlords lose while work is being carried out in a vacant property) (Greening UK, 2008). Another difficulty related to the economic costs or retrofitting revolves around who pays and who benefits from energy performance improvements. Many commercial buildings are rented and while owners are responsible for the costs of replacing inefficient equipment or improving the fabric of the building, it is occupiers that benefit from savings in their energy bills. More fundamentally, simple measures to make energy savings at practically no additional cost are often not 
implemented due to a significant disconnect between those owning/managing buildings and those paying the energy bills (Greening $U K, 2008)$. Besides barriers related to the availability of information on energy consumption, the economic costs of retrofitting and coordination between owners and occupiers, there are physical constraints that dictate what is feasible in terms of retrofitting buildings to make them more energy efficient (Greening UK, 2008).

Moreover, even if a landlord is willing to assume the additional costs and effort associated with making their property more socially and environmentally responsible, certain buildings may not be suitable for certain types of improvement (e.g., insulation measures may not be feasible in buildings with single leaf wall construction). "In addition, other issues such as the location of the building may effect its retrofitting options (e.g. lack of sufficient roof and wall surfaces on which to place photovoltaic cells and solar thermal panels)" (Greening UK, 2008). This has important implications for the design of policy instruments. In particular, existing stock cannot be retrofitted to comply with 'new build' standards. Therefore, different types of non-domestic buildings may require different benchmarks - albeit along a standard scale. An approach that rewards relative, rather than absolute, improvements may be the way forward. Simply rewarding the highest performer may have unintended consequences if most existing buildings cannot achieve the desired standard (Greening UK, 2008).

When considering LEED for a building project, it is crucial first to determine which points are achievable by the project. From there, an understanding of the potential costs of each achievable point can be developed (Matthiessen, 2004). The best and most economically sustainable designs are ones in which the features are incorporated at an 
early stage into the project, and where the features are integrated, effectively supporting each other (Matthiessen, 2004).

Once achievable points have been determined and the most economical design has been implemented the costs can be determined. At this point developers and investors could attempt to determine the precise "green premium" for a given project, but this is often very difficult for several reasons:

- Developers typically only issue specifications and costs for the designed building, not for other green options. Individual green items are sometimes priced out in comparison to non-green ones, but this is not the norm and does not provide a basis for cost comparison between green and conventional whole building design.

- Some green buildings being built today are showcase projects that may include additional and sometimes costly "finish" upgrades that are unrelated to greenness but that nonetheless are counted toward the green building cost increase.

- The design and construction process for the first green building of a client or design/architectural firm is often characterized by significant learning curve costs, and design schedule problems such as late and costly change orders.

- The relative newness of green technologies and systems can make designers, architects and clients conservative when using them. They may oversize green building systems and not fully integrate them into the building, thereby reducing cost savings and other benefits. Similarly, cost estimators may add uncertainty factors for new green technologies they are not familiar with, and these can compound, further inflating cost estimates (Kats, 2003). 
As developers and their partners ${ }^{12}$ gain more experience in the design of new projects and the retrofitting of existing buildings, the risks and premiums associated with green design and technologies will diminish, providing additional motivation for other development to follow suit.

\section{Contractors}

A typical construction project can employ executing entities as diverse as architects, various specialist engineers, general contractors, specialist subcontractors, and quantity surveyors (Matar, 2008). Apart from the variability in technical competence, the problems with existing specification practice are associated with the unclear delineation of responsibilities amongst stakeholders and the infrequent use of reliable templates (Lam, 2007). These problems have caused disputes and inconsistency of work quality in the construction process. When stakeholders wish to achieve sustainable construction through the use of green specifications, these problems must be mitigated and a lucid understanding of the factors involved in successful implementation of green specifications is essential (Lam, 2010).

Several barriers contribute to hindering sustainable construction ${ }^{13}$ being the dominant trend of the industry. Principally, these barriers can be summarized into two

\footnotetext{
${ }^{12}$ Partners may include such stakeholder as investors, architects, contractors, and engineers. They are the other parties that developers may collaborate with throughout the completion of a project.

${ }^{13}$ Sustainable Construction is construction that aims at reducing the environmental impact of a building over its entire lifetime, while optimizing its economic viability and the comfort and safety of its occupants.
} 
main categories: general barriers and technical barriers (Matar, 2004; Matar, 2007; Matar, 2008).

General Barriers to sustainability include:

1) The lack of expressed interest from different project parties (Du Plessis, 2002).

2) The lack of training/education in sustainable design/construction ( Du Plessis, 2002).

3) The slow or very slow recovery of investment in sustainable construction practices (Du Plessis, 2002; Reed, 2003).

4) The higher initial cost of sustainable building alternatives (Landman, 1999).

Technical barriers to sustainable construction include:

1) The lack of a well defined set of sustainable construction practices that can be practically engineered in construction projects (Pearce, 2002).

2) The need for mature and well-developed framework of application for sustainable practices in construction...Each of the currently available systems has its own set of assumptions and limitations, and is designed for utilization by specific participants in the building process (Scheuer, 2002). This hinders the capacity of different industry stakeholders to cooperate in a uniform and constructive way.

3) The disagreement about an optimum project delivery structure to attain sustainability. 
4) The need for effective drivers for change for different parties in the construction industry (Vanegas, 2000).

As sustainability becomes increasingly popular with other stakeholders these barriers will be removed. The development of sustainable construction guidelines, training and education of the workforce, reduced costs and faster recovery of investments will all result from industry progression toward and experience with sustainable design and construction, thereby allowing for the removal of contractors from the vicious circle of blame.

\section{Occupiers}

The common use of triple net leases is a disincentive to investments that reduce operating costs because owners and developers do not receive direct benefits unless tenants agree to higher lease rates (Broughton, 2006). When determining to what extent investors and developers should bear additional costs in efforts to design and construct more socially responsible property it is important to keep in mind that market factors dictate the rental level, but business productivity ultimately dictates the occupier's ability to pay (Ellison, 2006). It is therefore important to consider the economic impact green buildings have on occupiers. As noted by Fisk (2000), economic benefits may result from: (1) reduced health care costs; (2) reduced sick leave; and (3) a reduction in time when health effects diminish performance of workers while they are at work. The potential value of these employee-related benefits has been estimated in research conducted by Carnegie Mellon University for the General Services Administration in 1999. That research found that costs associated with employees amounted to 78 percent 
of total operations costs, while costs connected directly to the built environment - rent, operations and maintenance, and office moves - made up only 9 percent (Morton, 2002). Many of the cost/benefit studies conducted in the past have used these figures in attempts to estimate the economic gains attainable from improvements in the indoor environment offered by green buildings. However, even with the best of the information currently available, there is a high level of uncertainty with these estimates of the health and associated economic gains attainable from improvements in the indoor environment. In general, the largest source of uncertainty is the degree to which health effects could be reduced through practical changes in building design, operation, and maintenance (Fisk, 2000). As noted by Lucuik et al. (2005), there is limited statistically sound research into the benefits of green buildings, particularly in the area of productivity, which could be a key element in the acceptance of green buildings. In order for occupiers to actively seek out green buildings, concrete evidence of the economic benefits derived from green attributes must be presented.

If the economic benefits of green buildings for commercial property are indeed reflected in tenants' willingness to pay premiums on net rent for green spaces or in lower risk premiums for buildings, this would enable investors to offset the higher initial investment required for sustainable buildings, or even to command higher risk-adjusted returns. However, for real estate investors, hard evidence on the financial performance of green buildings is limited and consists mainly of industry-initiated case studies. To persuade property owners, developers and investors in the global marketplace of the benefits of "eco-investment," the payoff from investment in green buildings needs to be identified in that same marketplace (Eichholtz et al., 2009). 
As credible evidence of the economic gains attributable to green buildings begins to mount, tenants will begin to actively seek out socially responsible space, effectively removing themselves from the vicious circle of blame.

\section{Investors}

One of the key barriers identified by the Intergovernmental Panel on Climate Change to realizing sustainable real estate's potential was the availability of financing (Hagart, 2008). As property owners and debtors, real estate investors can influence how property-related issues are addressed. They can purchase and promote new buildings that are located and designed to create fewer negative and more positive impacts, and they can address issues through how they manage and refurbish their existing portfolios (Pivo, 2008).

In a recent study it was determined that the strongest drivers of Responsible Property Investing ${ }^{14}$ were conventional considerations such as concern for risk and return and opportunities to outperform [the market] (Pivo, 2008). However, for real estate investors, hard evidence on the financial performance of green buildings is limited and consists mainly of industry-initiated case studies. To persuade property owners, developers and investors in the global marketplace of the benefits of "eco-investment," the payoff from investment in green buildings needs to be identified in that same marketplace (Eichholtz, 2009). Clearly the costs of going green vary by local market, the number of vendors, and experience in the local market, developer/owner experience, and project or portfolio scale (Miller, 2008). Because of their impact on costs, these factors

\footnotetext{
${ }^{14}$ Responsible Property Investment is a term that captures all the ways that investors can find and create value through improving the economic, social, and environmental profile of their investments.
} 
all need to be taken into account by investors when determining whether or not to become engaged in a green building project.

Beyond the factors impacting project cost, one of the most important considerations for investors is how they go about their cost/benefit calculations. To date, the single most important justification mechanism for managers striving to make the case for sustainable buildings is life cycle costing, which is a modification of benefit/cost analysis that focuses more on cost reductions over time than near-term financial benefits. Nearly all of the benefits accrued with green building occur over the economic or design life of the building with a typical time horizon of 20-25 years. (Roper, 2006) "Beyond the [1-3 year] time frame, however, few decision-makers believe in the predictions of the cost of energy, or that they will still own the building and be accruing savings from the innovation"(Loftness, 2005).

In addition to the long payback periods faced by investors, there is also a lack of guidelines allowing them to clearly define what a green building is. "From a stock market perspective, the lack of a clear definition [on what constitutes a green building] is a significant issue. The market likes to benchmark, but there is no one clear benchmark of green or sustainable property or development" (Green Property: Does it Pay?, 2005). One way around this issue is in assessing the performance of groups of buildings ${ }^{15}$. If an index of performance of existing buildings correlating financial return and sustainability criteria is realized, then a market transformation will take place (Sayce, 2007).

\footnotetext{
${ }^{15}$ There are a number of ways that buildings may be evaluated in groups. Some examples include portfolios, trusts, or even indices.
} 
Asset flows indicate that investors are finding socially screened funds more attractive than other funds. According the Social Investment Forum, screened funds attract and retain investor assets longer than non-screened funds and socially responsible funds saw net inflows of $\$ 1.5$ billion during 2002 compared to a $\$ 10.5$ billion outflow for US diversified equity funds over the same period (Pivo, 2005). The vicious cycle has been broken, at least in part, although progress towards a virtuous wheel as envisaged by (Parnell, 2005) remains tenuous and focused on a small number of investors and developers. Empirical evidence points to greater awareness but only slight market movement (Sayce, 2007). While there seems to be consensus on the environmental and social benefits of green building there is a consistent concern, both within and outside the green building community, over the lack of accurate and thorough financial and economic information (Kats, 2003). In order for markets to progress towards socially responsible property investing, concrete evidence must be provided as to the worth ${ }^{16}$ of socially responsible property.

\section{Studies of Responsible Property Initiatives}

Many studies attempting to provide a complete cost/benefit analysis of socially and environmentally responsible property initiatives (such as LEED) have two major flaws that inhibit their ability to provide motivation for stakeholders to invest in socially and environmentally responsible property. First, they are fraught with assumptions that are backed by engineering calculations and surveys of opinion rather than factual

\footnotetext{
${ }^{16}$ Worth can be defined as the value of the property to a particular investor, or class of investors, for identified investment objectives (Lorenz, 2008).
} 
evidence. Second, the costs and benefits are based on a number of factors that may not be applicable to other projects.

The study performed by Kats (2003) is one of the most heavily cited cost/benefit analyses ever performed on green buildings. One of the main conclusions of this study was that green buildings are more comfortable and healthier for building occupants, in addition to supporting increases in productivity. Therefore they should be in greater demand than conventional buildings: achievable rents should be higher and vacancies lower. Although Kats' study does not prove there is a net financial benefit associated with green buildings, he does note that, "a study that tracks green buildings in the marketplace could confirm or deny this.” (Kats, 2003).

When buildings are tracked in the marketplace, occupancy (or vacancy) rates are commonly used as a portmanteau indicator of market conditions (Fuerst, 2009). The vast majority of the academic literature on vacancy levels has been on modeling regional or metropolitan levels typically focusing on their explanatory power in rent determination at the market level. Not surprisingly, these studies have tended to find a positive relationship between rent and occupancy rates. Essentially both rent and occupancy rates are analyzed as jointly determined and are modeled as outcomes of the interaction of the same supply and demand conditions (Fuerst, 2009). 
To date there have been a number of studies assessing the impact that LEED certification has on rental ${ }^{17}$ and occupancy rates. ${ }^{18}$ However, these studies have all provided assessment of markets outside of Canada. The first study investigating the financial implications of factoring environmental, social, and governance (ESG) considerations in real estate investment decision-making in Canada was that conducted by Hebb (2009). Although Hebb provides an analysis of the financial implications of factoring environmental, social and governance considerations in real estate investment decision-making in Canada, her study was not specific to the effects of LEED labeling. In addition, because Hebb's study used stock price performance rather than the more conventional measures of rental or occupancy rates, she was unable to find a statistically significant relationship. The reason for this, as noted by Hebb (2009), is that many other factors in the market influence the stock price changes of these firms to a greater degree than can be claimed by simply having high ESG standards.

So, although there have been a number of recent studies measuring market adoption of socially and environmentally responsible property initiatives, the majority of existing studies have focused on markets outside of Canada. Of the studies that have focused on Canadian markets, none have offered concrete evidence as to the impact on value of socially and environmentally responsible property initiatives such as LEED labeling.

\footnotetext{
${ }^{17}$ The Rental (or Lease) Rate is the rental payment made by lessee to a lesser for the use of assets for a specified period of time.

${ }^{18}$ The Occupancy Rate is the measure of capacity utilized within a building for a given year.
} 
A review of the literature indicates that property owners and investors are the stakeholder group with the power to decide how building issues get addressed, and should therefore be a focus in promoting market adoption of LEED. Furthermore, given that this stakeholder group is predominantly concerned with the financial implications of their decisions. That being the case, a second round of literature was reviewed to determine what factors have an impact on return on investment for property owners.

Research Objective 2 - What factors have an impact on return on investment for property owners?

\section{Literature Review (Part 2)}

There are a number of previous office studies that have assessed what factors have an impact on return on investment for property owners. The factors that have been shown to be significant determinants in office price modeling outlined in Table 1. To provide some context for the results of each study, the table also includes the sample size and dependent variable used, as well as the year and region in which the study was conducted.

Table 1: Studies of factors impacting office rents

\begin{tabular}{|c|c|c|c|c|}
\hline $\begin{array}{l}\text { Author } \\
\text { (study } \\
\text { year) }\end{array}$ & $\begin{array}{l}\text { Region } \\
\text { Studied }\end{array}$ & $\begin{array}{l}\text { Sample } \\
\text { Size }\end{array}$ & $\begin{array}{l}\text { Dependent } \\
\text { Variable }\end{array}$ & $\begin{array}{l}\text { Independent variables found to } \\
\text { be significant }\end{array}$ \\
\hline $\begin{array}{l}\text { Clapp } \\
(1980)\end{array}$ & $\begin{array}{l}\text { Los Angeles } \\
\text { Metropolitan } \\
\text { Area, USA }\end{array}$ & 105 & $\begin{array}{l}\text { Average } 1974 \\
\text { asking rent }\end{array}$ & $\begin{array}{ll}\text { - } & \text { Size } \\
\text { - } & \text { Age } \\
\text { - } & \text { Number of floors } \\
\text { - } & \text { Internal parking } \\
\text { - } & \text { Prestigious address } \\
\text { - } & \text { Property tax } \\
\end{array}$ \\
\hline
\end{tabular}




\begin{tabular}{|c|c|c|c|c|}
\hline & & & & $\begin{array}{ll}\text { - } & \text { Air quality } \\
\text { - } & \text { Amount of office space } \\
\text { within a two block } \\
\text { radius } \\
\text { - } \text { Distance by road to } \\
\text { nearest motorway } \\
\text { junction } \\
\text { - Average commuting } \\
\text { time for employees }\end{array}$ \\
\hline $\begin{array}{l}\text { Hough \& } \\
\text { Kratz } \\
(1983)\end{array}$ & $\begin{array}{c}\text { Chicago } \\
\text { Central } \\
\text { Business } \\
\text { District } \\
\text { (CBD), USA }\end{array}$ & 139 & $\begin{array}{c}\text { Average } 1978 \\
\text { asking rent }\end{array}$ & $\begin{array}{ll}\text { - } & \text { Existence of "good" } \\
\text { architecture } \\
\text { - } \\
\text { Distance from central } \\
\text { point of CBD } \\
\text { - } \text { Public Parking } \\
\text { - } \text { Age } \\
\text { - } \text { Size } \\
\text { - } \\
\text { - } \\
\text { Avumber of Floors } \\
\text { conference facility }\end{array}$ \\
\hline $\begin{array}{c}\text { Cannaday } \\
\text { \& Kang } \\
(1984)\end{array}$ & $\begin{array}{c}\text { Champaign- } \\
\text { Urbana, } \\
\text { Illinois, } \\
\text { USA }\end{array}$ & 24 & $\begin{array}{l}\text { Average } 1979- \\
80 \text { asking rent }\end{array}$ & $\begin{array}{l}\text { - Age } \\
\text { - Minimum lease term in } \\
\text { years } \\
\text { - "crow fly" distance to } \\
\text { the CBD } \\
\text { - "crow fly" distance to a } \\
\text { shopping centre } \\
\text { - Average unit size } \\
\text { - Average number of units } \\
\text { per floor }\end{array}$ \\
\hline $\begin{array}{l}\text { Brennan } \\
\text { et al. } \\
(1984)\end{array}$ & $\begin{array}{c}\text { Chicago } \\
\text { (CBD), USA }\end{array}$ & 29 & $\begin{array}{c}\text { Actual } \\
\text { transacted lease } \\
\text { values } \\
\text { (incorporating } \\
\text { lease terms) } \\
\text { within a } \\
\text { building from } \\
1980-1983\end{array}$ & $\begin{array}{ll}\text { - } & \text { Size of building } \\
\text { - } & \text { Size of each unit } \\
\text { - } & \text { Lease terms } \\
\text { - } & \text { Loss factor (proportion } \\
\text { of area rented but not } \\
\text { possible to use } \\
\text { - Position within the } \\
\text { building } \\
\text { - } \text { Location with respect to } \\
\text { centre of CBD }\end{array}$ \\
\hline $\begin{array}{l}\text { Glascock } \\
\text { et al. }\end{array}$ & $\begin{array}{l}\text { Baton } \\
\text { Rouge, } \\
\text { Louisiana, }\end{array}$ & 675 & $\begin{array}{l}\text { Asking rents of } \\
\text { office units }\end{array}$ & $\begin{array}{ll}\text { - } & \text { Location } \\
\text { - } & \text { Building type } \\
\text { - } & \text { Size }\end{array}$ \\
\hline
\end{tabular}


Shawn Roy

Thesis August 5, 2011

\begin{tabular}{|c|c|c|c|c|}
\hline (1990) & USA & & from $1985-1988$ & $\begin{array}{l}\text { - The year in which the } \\
\text { property was let }\end{array}$ \\
\hline $\begin{array}{l}\text { Mills } \\
(1992)\end{array}$ & $\begin{array}{c}\text { Chicago, } \\
\text { USA }\end{array}$ & 543 & $\begin{array}{l}\text { Asking rents \& } \\
\text { the discounted } \\
\text { rent over the } \\
\text { period of a } 15 \\
\text { year lease }\end{array}$ & $\begin{array}{ll}\text { - } & \text { Age } \\
\text { - } & \text { Size } \\
\text { - } & \text { Parking } \\
\text { - } & \text { Internal restaurant } \\
\text { - } & \text { Internal bank } \\
\text { - } & \text { Location outside the } \\
& \text { CBD (but not subsectors } \\
& \text { within the CBD) }\end{array}$ \\
\hline $\begin{array}{c}\text { Dunse \& } \\
\text { Jones } \\
(1998)\end{array}$ & $\begin{array}{l}\text { Glasgow, } \\
\text { Scotland }\end{array}$ & 477 & $\begin{array}{l}\text { Asking rents } \\
1994-1995\end{array}$ & $\begin{array}{l}\text { - Size } \\
\text { - Age } \\
\text { - } \text { Location } \\
\text { - Air conditioning } \\
\text { - Acoustic tiling } \\
\text { - } \text { Carpeting cellular layout } \\
\text { - } \text { Double glazing } \\
\text { - } \text { Raised floors } \\
\text { - Tea preparation area }\end{array}$ \\
\hline
\end{tabular}

Overall, location, age and size were the variables found to most consistently explain the variation in rents in these studies. Although each study shows a variety of building attributes to be significant, they appear significant on a less consistent basis than location age and size because the value attributed to them is unique to the particular office market studied. It is therefore important to note that, although previous studies can provide us with insight into which combinations of variables have been proven significant in past studies for other markets, their results are not transferable to the office market in downtown Toronto, Ontario. At best, a review of the literature allows us to develop a list of principal determinants of rent for local market areas that we can use to build a model for downtown Toronto, Ontario.

Research Objective 3 - Determine whether LEED is a significant contributor to a model accounting for the variance in office rents in downtown Toronto, Ontario. 
With knowledge of those variables that have been proven significant in past studies, quantitative analysis can now be used to determine what a model explaining the variance in office rents would look like, and whether LEED would be included in that model.

\section{Research Design and Methodology}

Globally there are more than 100 different types of environmental rating tools, however the well known tools include: LEED (USA and Canada), Energy Star (USA), BREEAM (United Kingdom), CASBEE (Japan), Green Star (Australia) and NABERS (Australia) just to name a few (Warren-Myers, 2009). The U.S. Green Building Council's Leadership in Energy and Environmental Design (LEED) rating system has been widely embraced both nationally and internationally as the green building standard (Kats, 2003). It was therefore decided that LEED would be the environmental rating tool evaluated in this study. In addition, when all building types are considered, the largest single source of greenhouse gas emissions in buildings came from offices (Reed, 2005), providing reason for this study to limit its attention to office buildings.

\section{Model Components}

The first step is to establish the buildings attributes to be accounted for in this study. As there are a number of variables that contribute to the heterogeneity of buildings, comparisons must draw upon a refined set of variables. In order to select the most relevant variables, only those specific attributes proven by past studies to be contributing significantly to building value will be chosen. 


\section{Data Collection}

The principal resource for developing a complete list of all LEED-labeled buildings in Canada was the Canadian Green Building Council. Information related to specific building variables for both LEED-labeled buildings and their comparables was obtained from Altus Group's Altus Insite database and Toronto City Hall's property assessment database. The the list of variables for which data was sought was influence by past studies (Clapp, 1980; Hough \& Kratz, 1983; Cannaday \& Kang, 1984; Dunse \& Jones, 1998), as this existing literature provided a preliminary research framework to prioritize what data should be collected and analyzed based on what variables have been proven significant in past studies.

To supplement the findings generated through quantitative analysis, phone interviews were held with three individuals uniquely qualified to provide an overview of trends in the downtown Toronto office rental market.. All interviewees were recruited by telephone. Three interviews were conducted with individuals either involved in deciding whether or not to pursue LEED certification or involved in the determination of asking rents for the subject properties. Each of the three interviewees were senior executives of commercial real estate development firms that held both LEED certified and non-LEED commercial office space in Toronto, Ontario. The inclusion of their viewpoints and experiences provides an understanding of the decisions related to certified and noncertified buildings in the study.

An interview protocol was used to guide the interviews. The interviews were semi-structured to provide room for probing (Patton, 2002). The interview protocol contained questions pertaining to the research objectives and was divided into three major 
parts: 1) background information about the decision (on whether or not to LEED certify) and the involvement of the interviewee in it; 2) their perception of the impact their decision has had/will have on the property value; and 3) their views regarding the future of LEED certification. The interviews lasted 15 to 30 minutes and were digitally recorded and transcribed with the consent of the interviewees.

Given its quantitative nature, this study does not rely primarily on interview data, but rather used it to glean additional insight into the figures produced by the model and to determine whether the perceptions of practitioners are congruent with study results.

\section{Data Analysis}

In keeping with the approach used in a number of building studies conducted in U.S. markets (Miller et al., 2008; Wiley et al. 2008; Eichholtz et al., 2009; Fuerst \& McAllister, 2009; Fuerst, 2009), Ordinary Least Squares analysis will be used to develop a model that best accounts for the variance in office rents and, ultimately, indicate whether LEED would be included in that model.

Ordinary least squares (OLS) is a method for estimating the unknown parameters in a linear regression model. This method minimizes the sum of squared vertical distances between the observed responses in a dataset, and the responses predicted by the linear approximation. The resulting estimator can be expressed by a version of the following formula:

$\mathrm{Y}=\mathrm{X} \beta+\varepsilon$

where $Y$ is an $n \times 1$ vector of observations on the regressand (i.e., the average net asking rent for a building), $X$ is a $n \times k$ matrix of observations of the regressors (e.g., 
building age, building class, existence of indoor parking, etc.), $\beta$ is a $k \times 1$ vector of unknown coefficients, and $\varepsilon$ is an $n \times 1$ vector of independent and identically distributed (i.i.d.) normal disturbances with zero mean and variance $\sigma^{2}$.

The goal of this analysis for the purposes of this research will be to develop a model that is best able to account for the variance in net asking rents (our regressand) and determine whether LEED is a significant contributor to a model accounting for the variance in office rents in downtown Toronto, Ontario.

\section{Application}

A review of the literature that has modeled office prices (Clapp, 1980; Hough \& Kratz, 1983; Cannaday \& Kang, 1984; Dunse \& Jones, 1998) has allowed this study to refine the list of variables to be included to those that have been consistently proven significant in past studies. As the variables which typically have a significant influence on property value have been established, they will be included in this study in conjunction with LEED certification to determine if LEED certification should be included in a model seeking to explain the variance in net asking rents.

\section{Assess the Impacts}

From these interconnected evaluations, an assessment of LEED-labeling's impact on property value will be made. The baseline building characteristics for properties included in this study provides a base for the generalizability of results and their applicability in 
demonstrating the impact of LEED-labeling across various scenarios. Each building characteristic will hold certain weight and in light of that, the various changes introduced (and their affects) will make it possible to evaluate the building as a whole. The evaluations will culminate in a valuation report that addresses the impact of LEEDlabeling on net asking rent.

\section{Analysis and Results}

This thesis research work will contribute to the study of responsible property investing in Canada by assessing the value of LEED certification in a major Canadian submarket (downtown Toronto, Ontario) while developing a model that will identify those determinants of office rents that are most significant in the study area. Although quantitative analysis has been performed in the past to assess the contribution of various attributes to property value, and there have been studies assessing the responsible property investing climate in Canada, this study will provide the first assessment of LEED certification's impact on net asking rents for office buildings in Canada specifically downtown Toronto, Ontario. Taking into account the relative infancy of the 'green' building movement in Canada and the impact that buildings are having on our environment, assessing whether (and to what degree) markets value socially responsible building initiatives will be helpful in developing government and industry policies and practices that seek to diminish the negative impacts of buildings while retaining (if not increasing) property value.

Although the results of this research will only be applicable to those areas for which building data will be studied, the model itself will serve as a point of reference for 
future studies of other markets within Canada and around the globe. The comparison of two submarkets in this study will provide for an accounting of various location characteristics that may impact the value of LEED in any given submarket but are not explicitly accounted for in this study.

\section{The study area and data}

\section{The study area: Toronto, Ontario}

The chosen study area is Toronto, Canada's largest city, which is situated in the Golden Horseshoe region of Ontario. The City of Toronto has 116 million square feet of office space, approximately 73 percent of the office space in the GTA making Toronto the largest office centre in Canada (City of Toronto, 2011). In addition, Toronto's downtown core is one of the most populated with LEED certified buildings in Canada (Canada Green Building Council, 2011), providing a large sample size that makes it appealing for use as a study area.

The buildings included in this study are taken from two areas of Toronto, downtown Toronto and Northern Toronto. Two areas are used because, as noted above, the comparison of two submarkets in this study will provide for an accounting of various location characteristics that may impact the value of LEED in any given submarket but are not explicitly accounted for in this study. The main office market is located in downtown Toronto, also referred to as the central business district (CBD) of Toronto, with a total office inventory of 69,060,133 square feet (Lambersky \& D'Souza, 2011) and 
an average gross rent ${ }^{19}$ of $\$ 34.52 /$ square foot. For the purposes of this study CBD will refer to the area bounded by Bloor to the North, Lake Ontario to the south, Don river to the East, and Bathurst street to the West. The buildings included in this study that fall outside of the CBD are approximately 13 kilometers North of 200 Bay Street ${ }^{20}$ and are within a 3.5 kilometer radius of one another. A total of 21 buildings were taken from Northern Toronto (four of which are LEED certified), while 47 buildings were taken from Toronto's CBD (12 of which are LEED certified).

\section{Data}

A sample of 24 LEED certified office buildings was obtained from the Canadian Green Building Council's list of Canadian LEED certified properties(Canada Green Building Council, 2011), and the list of 90 non-LEED comparable properties was obtained from the Toronto City Hall's building information database. Information related to building class ${ }^{21}$, total office area, year built, parking ratio, direct available rate, ${ }^{22}$ direct asking rate ${ }^{23}$ and total additional rent ${ }^{24}$ were all obtained from the Altus Insight database.

\footnotetext{
${ }^{19}$ Gross Rent is the monthly rent charged to occupy a premise which includes all operating costs (i.e., utilities, maintenance, taxes, etc.)

${ }^{20}$ For the purposes of this study 200 Bay Street is considered to be the centre point of the most prestigious office area in Toronto.

${ }^{21}$ The Building Owners and Managers Association (BOMA) classifies buildings based on a number of building and location characteristics as well as the ability to attract tenants at, above, or below market rents for the area. Based on these characteristics, buildings are subjectively ranked Class A, B or C.

${ }^{22}$ The Direct Available Rate, otherwise known as the Vacancy Rate is the percentage of all units that are unoccupied or not rented at a given time.

${ }^{23}$ Direct Asking Rate, otherwise known as the Net Asking Rate, is the amount the landlord hopes to receive from a rental property after deducting costs such as taxes, insurance, utilities, etc.
} 
Additional information related to direct asking rates and total additional rent that was not available from the database was obtained through phone calls to building leasing agents.

This study limited the inclusion of buildings to those that are office buildings in excess of 30,000 square feet and located within the study area. In addition, those buildings that were owner-occupied were eliminated from the study. For each LEED building included in the study attempts were made to include at least three non-LEED certified, but otherwise comparable properties. Ultimately, study specification and limitations related to data availability led to the inclusion of 16 LEED certified buildings and 52 non-LEED certified comparables.

Attempts to obtain information related to actual transacted rents through contact with a number of landlords, brokerage and research firms were unsuccessful. As a proxy, asking rents will be used as a measure of value. Although there was some concern about using asking rents rather than actual transaction price, Dunse and Jones (1998) found initial asking rent and final transacted rent to have a correlation coefficient of 0.98 , showing that the two variables are highly correlated and therefore providing justification for the use of asking rents as a proxy measure of value.

\section{Variable definitions}

The hedonic price model is estimated using regression analysis in which the dependant variable is asking rent, which will serve as a proxy for actual transacted rent values. The independent variables included are those that have been proven significant in similar past studies of other markets, and many of the variables are expressed as dummy

\footnotetext{
${ }^{24}$ Additional Rent is the portion of rent the tenant pays under the lease to cover expenses of the landlord.
} 
variables in a binary code. The analysis has been constrained due to study specifications resulting from a review of the literature as well as limitations related to data availability. There are a total of 12 variables, listed and described in Table 2, which describe the physical and location characteristics of each building.

Total office area relates to the capacity of the building. Although parking is the only variable related to physical structure, age and building class have been included as proxies for other variables related to a building's structure. Direct available rate and sublet area rate will serve as proxies to annual building vacancy rates. The direct asking rate serves as a proxy to actual transaction prices, and total additional rent is also included due to its impact on the gross rent that tenants pay.

The variables included in this study, although not an exhaustive list of building variables, are thought to comprise a comprehensive list of those variables believed to have a significant effect on net asking rent. Many building structure characteristics are excluded, although it is possible to argue that they are accounted for with the building class and age variables. Many location specific variables were excluded due to the clustering of the sample buildings included in the study. In their place, a calculation of each building's proximity or "crow fly" distance to the CBD centre point (200 Bay Street) was used to account for any variation in office rents related to building locationvariance usually associated with a prestigious address. 200 Bay Street is at the heart of Toronto's financial district, an area predominantly occupied by financial institutions and large professional practices and commands top rents for office space, providing justification for its use as the centre of the CBD in this study. 
Table 2: Variables and description of variables

\begin{tabular}{|c|c|c|c|}
\hline Variables & Variable Code & Measure & Description \\
\hline LEED Certified & LEED & $\begin{array}{l}\text { Dummy } \\
\text { Variable }\end{array}$ & $\begin{array}{l}\text { Indicates whether or not a } \\
\text { building is LEED certified }\end{array}$ \\
\hline $\begin{array}{l}\text { "Crow fly" Distance } \\
\text { from } 200 \text { Bay }\end{array}$ & CROW_FLY & Number & $\begin{array}{l}\text { The Euclidian distance } \\
\text { from the subject property } \\
\text { to } 200 \text { Bay St. }\end{array}$ \\
\hline Office Class A & CLASS_A & $\begin{array}{l}\text { Dummy } \\
\text { Variable }\end{array}$ & $\begin{array}{l}\text { Is it a Class A office } \\
\text { building, if yes }=1\end{array}$ \\
\hline Office Class B & CLASS_B & $\begin{array}{l}\text { Dummy } \\
\text { Variable }\end{array}$ & $\begin{array}{l}\text { Is it a Class B office } \\
\text { building, if yes }=1\end{array}$ \\
\hline Office Class C & CLASS_C & $\begin{array}{l}\text { Dummy } \\
\text { Variable }\end{array}$ & $\begin{array}{l}\text { Is it a Class } C \text { office } \\
\text { building, if yes }=1\end{array}$ \\
\hline Total Office Area & OFFICE_AREA & Number & $\begin{array}{l}\text { Total building square } \\
\text { footage }\end{array}$ \\
\hline Building Age & AGE & Number & The age of the building \\
\hline Parking Ratio & PARKING_RATIO & Number & $\begin{array}{l}\text { The number of parking } \\
\text { stalls per } 1,000 / \text { sq.ft. of } \\
\text { leasable office space }\end{array}$ \\
\hline $\begin{array}{c}\text { Direct Available } \\
\text { Rate }\end{array}$ & DIRECT & Number & $\begin{array}{l}\text { The percentage of the } \\
\text { building space available } \\
\text { for lease from the landlord } \\
\text { at the time of study }\end{array}$ \\
\hline Sublet Area Rate & SUB_AVAIL & Number & $\begin{array}{l}\text { The percentage of the } \\
\text { building space available } \\
\text { for lease from an existing } \\
\text { tenant at the time of the } \\
\text { study }\end{array}$ \\
\hline Direct Asking Rate & NET_RENT & Number & $\begin{array}{l}\text { The asking rent (per } \\
\text { square foot) }\end{array}$ \\
\hline $\begin{array}{c}\text { Total Additional } \\
\text { Rent }\end{array}$ & ADD_RENT & Number & $\begin{array}{l}\text { The additional charges } \\
\text { (per square foot) above } \\
\text { and beyond asking rent }\end{array}$ \\
\hline
\end{tabular}


Table 3: Binary Coding of Building Class

\begin{tabular}{|l|l|l|}
\hline & CLASS_B & CLASS_C \\
\hline Office Class A & 0 & 0 \\
\hline Office Class B & 1 & 0 \\
\hline Office Class C & 0 & 1 \\
\hline
\end{tabular}

\section{Results}

Before conducting the regression analysis, a correlation matrix was developed to determine each variable's level of explanatory power. The correlation matrix in Table 4 was then used to conduct a Ordinary Least Squares (OLS) analysis to determine which compilation of variables creates the equation that best accounted for the variance in net asking rents. In the analysis, the independent variable with the highest partial correlation coefficient to net asking rent is entered first into the model. This process is continued by adding the variable with the next highest partial correlation coefficient to the model and the adjusted $R^{2}$ for the new model is evaluated to compare its explanatory power ${ }^{25}$ to that of the previous model. This process is continued until all of those variables with a partial coefficient significant at the 0.05 level have been added to the model to assess their impact on the model's explanatory power. In addition, as new variables are added to the model, previous variables are removed from the equation if their significance level falls below the 10 percent critical value.

\footnotetext{
${ }^{25}$ The explanatory power of the model is the proportion of variability in a dataset that is accounted for by the stastical model. In this study, adjusted $R^{2}$ is used to measure the model's explanatory power because unlike $R^{2}$, which increases when a new term is added to the model, adjusted $R^{2}$ only increases if the new term improves the model more than would be expected by chance.
} 
Table 4: Correlation Matrix

\begin{tabular}{|c|c|c|c|c|c|c|c|c|c|c|c|c|}
\hline \multicolumn{13}{|c|}{ Correlations } \\
\hline & $\begin{array}{l}\llcorner \\
\mathbf{u} \\
\widetilde{\sim} \\
\stackrel{\mathrm{u}}{\mathrm{z}}\end{array}$ & 岂 & 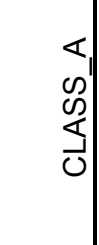 & 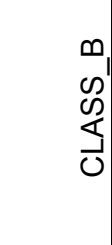 & \begin{tabular}{l}
0 \\
0 \\
$\infty$ \\
$\infty$ \\
\multirow{S}{1}{} \\
0
\end{tabular} & 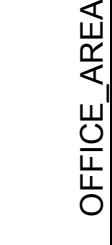 & 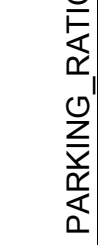 & $\begin{array}{l}\mathrm{U} \\
\mathrm{O} \\
\end{array}$ & $\begin{array}{l}\vdash \\
\breve{u} \\
\underline{\underline{\Delta}}\end{array}$ & 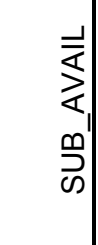 & 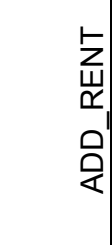 & 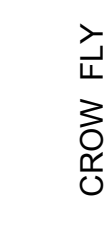 \\
\hline NET_RENT & 1 & .193 & $.489^{* * *}$ & $-.428^{* *}$ & -.198 & $.566^{* *}$ & $.616^{* *}$ & .089 & .214 & -.032 & $.873^{* *}$ & $-.608^{* *}$ \\
\hline LEED & & 1 & $.394^{* *}$ & $-.367^{* *}$ & -.102 & .230 & .190 & -.197 & -.060 & .025 & .240 & -.104 \\
\hline CLASS_A & & & 1 & $-.931^{* *}$ & $-.260^{*}$ & $.390^{* *}$ & $.368^{* *}$ & -.196 & .001 & -.069 & $.489^{* *}$ & -.110 \\
\hline CLASS_B & & & & 1 & -.110 & $-.348^{* *}$ & $-.303^{*}$ & .185 & .008 & .019 & $-.406^{* *}$ & .081 \\
\hline CLASS_C & & & & & 1 & -.144 & -.201 & .042 & -.022 & .137 & $-.256^{*}$ & .085 \\
\hline OFFICE_AREA & & & & & & 1 & $.550^{* *}$ & -.089 & .198 & -.063 & $.650^{* *}$ & $-.297^{*}$ \\
\hline PARKING_RATIO & & & & & & & 1 & .113 & .135 & -.230 & $.649^{* *}$ & $-.455^{* *}$ \\
\hline AGE & & & & & & & & 1 & -.109 & .058 & .031 & -.171 \\
\hline DIRECT & & & & & & & & & 1 & -.038 & .172 & .060 \\
\hline SUB_AVAIL & & & & & & & & & & 1 & .015 & -.152 \\
\hline ADD_RENT & & & & & & & & & & & 1 & $-.576^{* *}$ \\
\hline CROW_FLY & & & & & & & & & & & & 1 \\
\hline
\end{tabular}

**. Correlation is significant at the 0.01 level (2-tailed).

*. Correlation is significant at the 0.05 level (2-tailed).

In order to gain some understanding of the relationship between LEED and the other coefficients included in the matrix, we will analyze the correlation ${ }^{26}$ between them. The two coefficients most heavily correlated with LEED are CLASS_A and CLASS_B, with correlation coefficients of .394 and -.367 respectively. These two variables having a correlation with LEED that is significant at the 0.01 level is likely the result of all LEED certified buildings included in the sample being Class A buildings, thereby resulting in a strong positive correlation with CLASS_A and a strong negative correlation with

\footnotetext{
${ }^{26}$ The correlation between two coefficients tells us the extent to which, as one variable increases, the other increases/decreases.
} 
CLASS_B.CLASS_C is also negatively correlated with LEED, but not to the same degree as CLASS_B, this is likely due to the fact that there were far fewer Class C buildings included in the study than there were Class A and B.

Next we see that ADD_RENT and OFFICE_AREA are positively correlated with LEED, with correlation coefficients of .240 and .230 respectively. Office area is positively correlated with LEED certification because the buildings in the sample that were LEED certified tended to be larger buildings. It follows that larger office buildings are also those that are more likely to have a large amount of common area and more amenities, thereby increasing the amount of additional rent charged to tenants.

The remaining coefficients that are positively correlated with LEED are PARKING_RATIO and SUB_AVAIL, with correlation coefficients of .190 and .025 respectively. These correlations tell us that LEED buildings may have more parking and more sublet space available, but given the low level of significance obtained by these correlations, any attempt to generalize these statements would be unlikely to hold much water.

We then have those remaining coefficients that were negatively correlated with LEED, those being AGE, CROW_FLY and DIRECT, with correlation coefficients of $-.197,-.104$ and -.06 respectively. These figures tell us that LEED buildings tend to be newer properties, likely situated near the centre of the $\mathrm{CBD}$, with lower than average vacancy. Again, however, the low level of significance of these obtained by these correlations makes it difficult to generalize these statements beyond the study sample. 
Finally, we look at the .193 correlation between NET_RENT (our dependent variable) and LEED. Although this correlation is near significance, possibly telling us that LEED buildings obtain higher net rents, this could also be the result of multicollinearity with other variables that have high positive correlations with NET_RENT.

Now that the relationships between LEED and the other coefficients considered for the model have been analyzed, we will now begin to build our model.

The first variable to be included in the model, with a partial correlation coefficient of .873 , is additional rent.

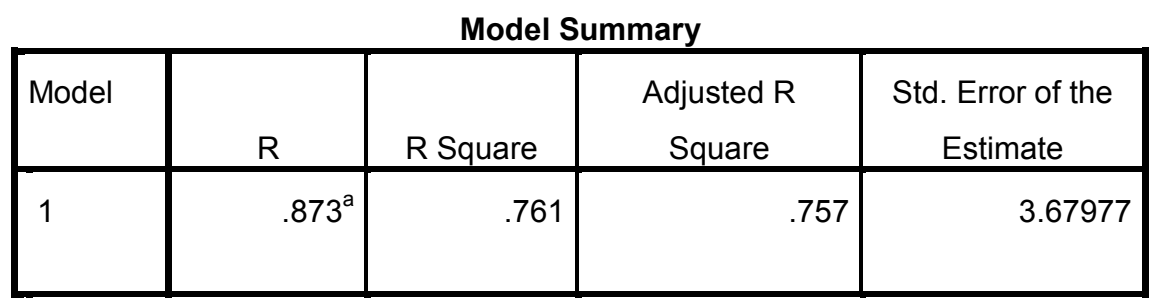

a. Predictors: (Constant), ADD_RENT

ANOVA $^{\text {b }}$

\begin{tabular}{|ll|r|r|r|r|r|}
\hline Model & & Sum of Squares & \multicolumn{1}{|c|}{ df } & Mean Square & \multicolumn{1}{c|}{ F } & \multicolumn{1}{c|}{ Sig. } \\
\hline 1 & Regression & 2720.370 & 1 & 2720.370 & 200.903 & $.000^{\mathrm{a}}$ \\
& Residual & 853.067 & 63 & 13.541 & & \\
& Total & 3573.437 & 64 & & & \\
\hline
\end{tabular}

a. Predictors: (Constant), ADD_RENT

b. Dependent Variable: NET_RENT

Coefficients $^{a}$

\begin{tabular}{|c|c|c|c|c|c|}
\hline \multirow[t]{2}{*}{ Model } & \multicolumn{2}{|c|}{ Unstandardized Coefficients } & $\begin{array}{c}\text { Standardized } \\
\text { Coefficients }\end{array}$ & \multirow[b]{2}{*}{$t$} & \multirow[b]{2}{*}{ Sig. } \\
\hline & B & Std. Error & Beta & & \\
\hline
\end{tabular}




\begin{tabular}{|c|c|c|c|c|c|c|}
\hline 1 & (Constant) & -7.747 & 2.130 & & -3.636 & .001 \\
\hline & ADD RENT & 1.350 & .095 & .873 & 14.174 & .000 \\
\hline
\end{tabular}

a. Dependent Variable: NET_RENT

This initial model returned an adjusted $R^{2}$ of .757 , with additional rent significant at the 99 percent critical value level. This is a very high adjusted $R^{2}$ and may be cause for concern that 'additional rent' might be drowning out the effect that other variables (including LEED) might have on net asking rent, especially when considering the high degree of correlation between additional rent and the other predictor variables. That being said, the process of adding and removing variables from the model based on their partial correlation coefficients and significance levels was continued until we arrived at a model consisting of ADD_RENT and CLASS_B.

\begin{tabular}{|l|r|r|r|r|}
\hline Model & Model Summary \\
\hline 1 & $\mathrm{R}$ & $\mathrm{R}$ Square & $\begin{array}{c}\text { Adjusted R } \\
\text { Square }\end{array}$ & $\begin{array}{c}\text { Std. Error of the } \\
\text { Estimate }\end{array}$ \\
\hline & $.881^{\mathrm{a}}$ & .776 & .769 & 3.59315 \\
\hline
\end{tabular}

a. Predictors: (Constant), CLASS_B, ADD_RENT

\begin{tabular}{|ll|r|r|r|r|r|}
\hline \multicolumn{7}{|c|}{ ANOVA $^{\mathbf{b}}$} \\
\hline 1 & Sum of Squares & df & Mean Square & F & Sig. \\
\hline & Regression & 2772.972 & 2 & 1386.486 & 107.390 & $.000^{\mathrm{a}}$ \\
& Residual & 800.464 & 62 & 12.911 & & \\
& Total & 3573.437 & 64 & & & \\
\hline
\end{tabular}

a. Predictors: (Constant), CLASS_B, ADD_RENT

b. Dependent Variable: NET_RENT

\section{Coefficients $^{\mathrm{a}}$}

\begin{tabular}{|l|c|c|c|c|}
\hline Model & & Standardized & & \\
& Unstandardized Coefficients & Coefficients & $\mathrm{t}$ & Sig. \\
\hline
\end{tabular}




\begin{tabular}{|c|c|c|c|c|c|c|}
\hline & & $B$ & Std. Error & Beta & & \\
\hline \multirow[t]{3}{*}{1} & (Constant) & -5.585 & 2.340 & & -2.387 & .020 \\
\hline & ADD_RENT & 1.277 & .100 & .826 & 12.808 & .000 \\
\hline & CLASS B & -2.195 & 1.087 & -.130 & -2.018 & .048 \\
\hline
\end{tabular}

a. Dependent Variable: NET_RENT

The model produced an adjusted $R^{2}$ of .769 , with ADD_RENT significant at the 99 percent critical value level and CLASS_B significant at the 95 percent critical value level.

The exclusion of many variables from the "best" model is explicable when we look at the relation of each to additional rent while taking into consideration the characteristics of the sample buildings. The first variable that was removed from the model was PARKING_RATIO, which has a partial correlation coefficient of .616 yet could still not be deemed significant in a model that already included ADD_RENT. As ADD_RENT is typically a composition of those costs associated with property taxes, common area maintenance and any other additional expenses the landlord may charge that related to building maintenance and services, the greater the amount of common area a building posses, the higher the additional rent will be. Those buildings with the greatest amount of common area in downtown Toronto happen to be located in the $\mathrm{CBD}$, an area where reserved parking is rare and highly sought after. When linking the value placed on parking in the $\mathrm{CBD}$ with the higher additional rents in the area, it is understandable why the significance of parking may have been drowned out by the ADD_RENT variable.

As we go down the list of variables with high individual correlation coefficients we can see that the same effect was had on CROW_FLY and OFFICE_AREA, as these 
variables are affected by proximity to the centre point of the CBD. CROW_FLY is affected because it is actually a measure of building proximity to the centre of the CBD, while OFFICE_AREA is affected because the buildings in downtown Toronto with the greatest amount of office space are those in the centre of the city's CBD. The only other variable excluded from the model with a significant individual correlation to net asking rent was CLASS_A, which was excluded because it was replaced by CLASS_B which reduced its significance and provided a model with a higher adjusted $R^{2}$. The large changes in the regression coefficients produced by the inclusion of ADD_RENT in the model are an indication of multicollinearity. The same can be said for the relationship between CLASS_A and CLASS_B, however the multicollinearity that exists between these two variables was expected as they are both indicators of building class, but both were evaluated to see which contributed most significantly to the model.

In an attempt to reduce multicollinearity, a second stepwise regression analysis was performed that excluded ADD_RENT from the model. The first variable included in the new model was PARKING_RATIO, resulting in an $\mathrm{R}_{\text {ajd }}^{2}$ of .370 with the parking ratio significant at the 99 percent critical value level.

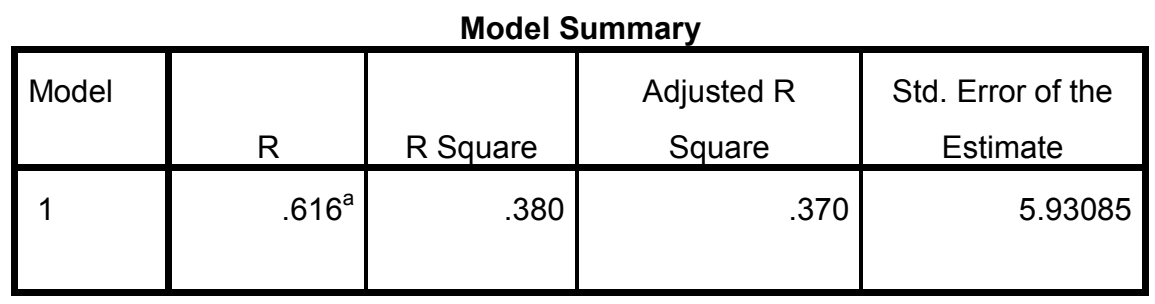

a. Predictors: (Constant), PARKING_RATIO

ANOVA $^{\text {b }}$

\begin{tabular}{|c|c|c|c|c|c|}
\hline Model & Sum of Squares & $d f$ & Mean Square & $\mathrm{F}$ & Sig. \\
\hline Regression & 1357.415 & 1 & 1357.415 & 38.590 & $.000^{\mathrm{a}}$ \\
\hline
\end{tabular}


Thesis August 5, 2011

\begin{tabular}{|l|l|l|l|l|}
\hline Residual & 2216.022 & 63 & 35.175 & \\
Total & 3573.437 & 64 & & \\
\hline
\end{tabular}

a. Predictors: (Constant), PARKING_RATIO

b. Dependent Variable: NET_RENT

\section{Coefficients $^{a}$}

\begin{tabular}{|c|c|c|c|c|c|c|}
\hline \multirow{2}{*}{\multicolumn{2}{|c|}{ Model }} & \multicolumn{2}{|c|}{ Unstandardized Coefficients } & \multirow{2}{*}{$\begin{array}{c}\begin{array}{c}\text { Standardized } \\
\text { Coefficients }\end{array} \\
\text { Beta }\end{array}$} & \multirow[b]{2}{*}{$\mathrm{t}$} & \multirow[b]{2}{*}{ Sig. } \\
\hline & & $\mathrm{B}$ & Std. Error & & & \\
\hline \multirow[t]{2}{*}{1} & (Constant) & 16.620 & 1.105 & & 15.035 & .000 \\
\hline & PARKING_RATIO & .003 & .001 & .616 & 6.212 & .000 \\
\hline
\end{tabular}

a. Dependent Variable: NET_RENT

Next, CROW_FLY was added to the model, returning an adjusted $R^{2}$ of .501

while both coefficients maintained significance at the 99 percent critical value level.

Model Summary

\begin{tabular}{|l|r|r|r|r|}
\hline Model & $\mathrm{R}$ & $\mathrm{R}$ Square & \multicolumn{1}{c|}{$\begin{array}{c}\text { Adjusted R } \\
\text { Square }\end{array}$} & $\begin{array}{c}\text { Std. Error of the } \\
\text { Estimate }\end{array}$ \\
\hline 1 & $.719^{\mathrm{a}}$ & .516 & .501 & 5.28014 \\
\hline
\end{tabular}

a. Predictors: (Constant), CROW_FLY, PARKING_RATIO

ANOVA $^{b}$

\begin{tabular}{|ll|r|r|r|r|r|}
\hline Model & Sum of Squares & df & Mean Square & F & Sig. \\
\hline 1 & Regression & 1844.885 & 2 & 922.443 & 33.086 & $.000^{\mathrm{a}}$ \\
& Residual & 1728.551 & 62 & 27.880 & & \\
& Total & 3573.437 & 64 & & & \\
\hline
\end{tabular}

a. Predictors: (Constant), CROW_FLY, PARKING_RATIO

b. Dependent Variable: NET_RENT

Coefficients $^{a}$

Model

Standardized

Coefficients 
Shawn Roy

Thesis August 5, 2011

\begin{tabular}{|c|c|c|c|c|c|c|}
\hline & & $\mathrm{B}$ & Std. Error & Beta & & \\
\hline \multirow[t]{3}{*}{1} & (Constant) & 20.624 & 1.373 & & 15.020 & .000 \\
\hline & PARKING_RATIO & .002 & .001 & .430 & 4.344 & .000 \\
\hline & CROW_FLY & -.001 & .000 & -.414 & -4.181 & .000 \\
\hline
\end{tabular}

a. Dependent Variable: NET_RENT

OFFICE_AREA was then included, increasing the adjusted $R^{2}$ to .552 , and although CROW_FLY and OFFICE_AREA remained significant at the 99 percent critical value level, PARKING_RATIO's significance was reduced to the 95 percent critical value level.

Model Summary

\begin{tabular}{|c|c|c|c|c|}
\hline Model & $\mathrm{R}$ & R Square & $\begin{array}{c}\text { Adjusted R } \\
\text { Square }\end{array}$ & $\begin{array}{c}\text { Std. Error of the } \\
\text { Estimate }\end{array}$ \\
\hline 1 & $.757^{a}$ & .573 & .552 & 5.00293 \\
\hline
\end{tabular}

a. Predictors: (Constant), OFFICE_AREA, CROW_FLY, PARKING_RATIO

ANOVA $^{\mathrm{b}}$

\begin{tabular}{|ll|r|r|r|r|r|}
\hline Model & & Sum of Squares & df & Mean Square & F & Sig. \\
\hline 1 & Regression & 2046.647 & 3 & 682.216 & 27.257 & $.000^{\mathrm{a}}$ \\
& Residual & 1526.790 & 61 & 25.029 & & \\
& Total & 3573.437 & 64 & & & \\
\end{tabular}

a. Predictors: (Constant), OFFICE_AREA, CROW_FLY, PARKING_RATIO

b. Dependent Variable: NET_RENT

\section{Coefficients $^{a}$}

\begin{tabular}{|c|c|c|c|c|c|c|}
\hline \multirow{2}{*}{\multicolumn{2}{|c|}{ Model }} & \multicolumn{2}{|c|}{ Unstandardized Coefficients } & \multirow{2}{*}{$\begin{array}{c}\text { Standardized } \\
\text { Coefficients } \\
\text { Beta }\end{array}$} & \multirow[b]{2}{*}{$\mathrm{t}$} & \multirow[b]{2}{*}{ Sig. } \\
\hline & & $\mathrm{B}$ & Std. Error & & & \\
\hline \multirow[t]{3}{*}{1} & (Constant) & 19.694 & 1.342 & & 14.679 & .000 \\
\hline & PARKING_RATIO & .001 & .001 & .279 & 2.585 & .012 \\
\hline & CROW_FLY & .000 & .000 & -.392 & -4.169 & .000 \\
\hline
\end{tabular}




\begin{tabular}{|l|r|r|r|r|r|}
\hline OFFICE_AREA & $5.328 \mathrm{E}-6$ & .000 & .288 & 2.839 & .006 \\
\hline
\end{tabular}

a. Dependent Variable: NET_RENT

When CLASS_A is added to the model we see PARKING_RATIO and OFFICE_AREA's significance reduced to the 90 and 95 percent critical value levels respectively, while CROW_FLY and CLASS_A are significant at the 99 percent critical value levels and the model's adjusted $R^{2}$ moves to .604 .

Model Summary

\begin{tabular}{|l|r|r|r|c|}
\hline Model & $\mathrm{R}$ & $\mathrm{R}$ Square & \multicolumn{1}{c|}{$\begin{array}{c}\text { Adjusted R } \\
\text { Square }\end{array}$} & $\begin{array}{c}\text { Std. Error of the } \\
\text { Estimate }\end{array}$ \\
\hline 1 & $.793^{\mathrm{a}}$ & .629 & .604 & 4.70200 \\
\hline
\end{tabular}

a. Predictors: (Constant), CLASS_A, CROW_FLY, OFFICE_AREA, PARKING_RATIO

ANOVA $^{\text {b }}$

\begin{tabular}{|ll|r|r|r|r|r|}
\hline \multicolumn{1}{|l|}{ Model } & Sum of Squares & df & Mean Square & F & Sig. \\
\hline 1 & Regression & 2246.908 & 4 & 561.727 & 25.407 & $.000^{\mathrm{a}}$ \\
& Residual & 1326.528 & 60 & 22.109 & & \\
& Total & 3573.437 & 64 & & & \\
\hline
\end{tabular}

a. Predictors: (Constant), CLASS_A, CROW_FLY, OFFICE_AREA, PARKING_RATIO

b. Dependent Variable: NET_RENT

\begin{tabular}{|c|c|c|c|c|c|c|}
\hline \multicolumn{7}{|c|}{ Coefficients $^{a}$} \\
\hline \multirow{2}{*}{\multicolumn{2}{|c|}{ Model }} & \multicolumn{2}{|c|}{ Unstandardized Coefficients } & \multirow{2}{*}{$\begin{array}{c}\begin{array}{c}\text { Standardized } \\
\text { Coefficients }\end{array} \\
\text { Beta }\end{array}$} & \multirow[b]{2}{*}{$\mathrm{t}$} & \multirow[b]{2}{*}{ Sig. } \\
\hline & & $B$ & Std. Error & & & \\
\hline \multirow[t]{5}{*}{1} & (Constant) & 17.839 & 1.404 & & 12.710 & .000 \\
\hline & PARKING_RATIO & .001 & .001 & .200 & 1.907 & .061 \\
\hline & CROW_FLY & .000 & .000 & -.409 & -4.616 & .000 \\
\hline & OFFICE_AREA & 4.192E-6 & .000 & .226 & 2.324 & .024 \\
\hline & CLASS_A & 4.311 & 1.432 & .264 & 3.010 & .004 \\
\hline
\end{tabular}


Shawn Roy

Thesis August 5, 2011

\begin{tabular}{|c|c|c|c|c|c|c|}
\hline \multicolumn{7}{|c|}{ Coefficients $^{a}$} \\
\hline \multirow{2}{*}{\multicolumn{2}{|c|}{ Model }} & \multicolumn{2}{|c|}{ Unstandardized Coefficients } & \multirow{2}{*}{$\begin{array}{c}\text { Standardized } \\
\text { Coefficients } \\
\text { Beta }\end{array}$} & \multirow[b]{2}{*}{$\mathrm{t}$} & \multirow[b]{2}{*}{ Sig. } \\
\hline & & $\mathrm{B}$ & Std. Error & & & \\
\hline \multirow[t]{5}{*}{1} & (Constant) & 17.839 & 1.404 & & 12.710 & .000 \\
\hline & PARKING_RATIO & .001 & .001 & .200 & 1.907 & .061 \\
\hline & CROW_FLY & .000 & .000 & -.409 & -4.616 & .000 \\
\hline & OFFICE_AREA & 4.192E-6 & .000 & .226 & 2.324 & .024 \\
\hline & CLASS_A & 4.311 & 1.432 & .264 & 3.010 & .004 \\
\hline
\end{tabular}

a. Dependent Variable: NET_RENT

Finally, CLASS_B is introduced to the model, but subsequently removed due to its negative effect on the significance of the other variables and adjusted $R^{2}$.

Model Summary

\begin{tabular}{|c|c|c|c|c|}
\hline Model & $\mathrm{R}$ & R Square & $\begin{array}{c}\text { Adjusted R } \\
\text { Square }\end{array}$ & $\begin{array}{c}\text { Std. Error of the } \\
\text { Estimate }\end{array}$ \\
\hline 1 & $.779^{a}$ & .607 & .581 & 4.83646 \\
\hline
\end{tabular}

a. Predictors: (Constant), CLASS_B, CROW_FLY, OFFICE_AREA, CLASS_A

ANOVA $^{\mathrm{b}}$

\begin{tabular}{|ll|r|r|r|r|r|}
\hline Model & & Sum of Squares & df & Mean Square & F & Sig. \\
\hline 1 & Regression & 2169.955 & 4 & 542.489 & 23.192 & $.000^{\mathrm{a}}$ \\
& Residual & 1403.482 & 60 & 23.391 & & \\
& Total & 3573.437 & 64 & & & \\
\end{tabular}

a. Predictors: (Constant), CLASS_B, CROW_FLY, OFFICE_AREA, CLASS_A

b. Dependent Variable: NET_RENT

Coefficients $^{a}$

Model

\begin{tabular}{|c|c|c|c|c|}
\hline Unstandardized Coefficients & $\begin{array}{c}\text { Standardized } \\
\text { Coefficients }\end{array}$ & & \\
\cline { 1 - 3 } B & Std. Error & Beta & $\mathrm{t}$ & Sig. \\
\hline
\end{tabular}




\begin{tabular}{|l|r|r|r|r|r|}
\hline 1 & 17.565 & 3.518 & & 4.992 & .000 \\
CROW_FLY & -.001 & .000 & -.468 & -5.487 & .000 \\
OFFICE_AREA & $5.595 \mathrm{E}-6$ & .000 & .302 & 3.312 & .002 \\
CLASS_A & 6.255 & 3.565 & .384 & 1.754 & .084 \\
CLASS_B & 1.395 & 3.622 & .083 & .385 & .701 \\
\hline
\end{tabular}

a. Dependent Variable: NET_RENT

Therefore, our "best" model is comprised of the coefficients PARKING_RATIO, CROW_FLY, OFFICE_AREA and CLASS_A, producing an adjusted $R^{2}$ of .604 .

According to the correlation matrix, LEED certification's correlation with net asking rent is not significant at the .05 level, which would normally disqualify it from inclusion into the model, but regressions were still conducted to assess the impact of LEED on our "best" model's explanatory power.

Model Summary

\begin{tabular}{|l|r|r|r|r|}
\hline Model & R & R Square & \multicolumn{1}{|c|}{$\begin{array}{c}\text { Adjusted R } \\
\text { Square }\end{array}$} & $\begin{array}{c}\text { Std. Error of the } \\
\text { Estimate }\end{array}$ \\
\hline 1 & $.780^{\mathrm{a}}$ & .609 & .583 & 4.82678 \\
\hline
\end{tabular}

a. Predictors: (Constant), LEED, CROW_FLY, OFFICE_AREA, CLASS_A

ANOVA $^{b}$

\begin{tabular}{|ll|r|r|r|r|r|}
\hline \multicolumn{1}{|l|}{ Model } & Sum of Squares & df & Mean Square & F & Sig. \\
\hline 1 & Regression & 2175.567 & 4 & 543.892 & 23.345 & $.000^{\mathrm{a}}$ \\
& Residual & 1397.870 & 60 & 23.298 & & \\
& Total & 3573.437 & 64 & & & \\
\hline
\end{tabular}

a. Predictors: (Constant), LEED, CROW_FLY, OFFICE_AREA, CLASS_A

b. Dependent Variable: NET_RENT 


\begin{tabular}{|c|c|c|c|c|c|c|}
\hline \multirow{2}{*}{\multicolumn{2}{|c|}{ Model }} & \multicolumn{2}{|c|}{ Unstandardized Coefficients } & \multirow{2}{*}{$\begin{array}{c}\begin{array}{c}\text { Standardized } \\
\text { Coefficients }\end{array} \\
\text { Beta }\end{array}$} & \multirow[b]{2}{*}{$\mathrm{t}$} & \multirow[b]{2}{*}{ Sig. } \\
\hline & & $\mathrm{B}$ & Std. Error & & & \\
\hline \multirow[t]{5}{*}{1} & (Constant) & 18.824 & 1.341 & & 14.038 & .000 \\
\hline & CROW_FLY & -.001 & .000 & -.471 & -5.535 & .000 \\
\hline & OFFICE_AREA & 5.697E-6 & .000 & .308 & 3.373 & .001 \\
\hline & CLASS_A & 5.306 & 1.507 & .325 & 3.520 & .001 \\
\hline & LEED & -.925 & 1.482 & -.055 & -.624 & .535 \\
\hline
\end{tabular}

a. Dependent Variable: NET_RENT

Ultimately, when LEED was introduced to the model all original model coefficients fell within their original significance levels, but LEED was not shown to be statistically significant (.528), pulling adjusted $R^{2}$ down to .600 . It was therefore concluded that LEED certification should remain excluded as it did not improve the explanatory power of the model.

\section{Views of Practitioners}

With results of the regression showing LEED certification having no statistically significant impact on the model's ability to explain net asking rents, phone interviews were held with three individuals uniquely qualified to provide an overview of trends in the downtown Toronto office rental market. These interviews were conducted in attempts to gain insight into why LEED is being adopted in downtown Toronto, despite evidence 
that it does not have a significant impact on rents. What follows is a synopsis of those interviews $^{27}$ :

Table 5: Synopsis of Interviews

\begin{tabular}{|l|l|l|l|}
\hline & Interviewee 1 & Interviewee 2 & Interviewee 3 \\
\hline $\begin{array}{l}\text { Does LEED certification currently have } \\
\text { a significant impact on achievable gross } \\
\text { rent? }\end{array}$ & No. & No. & No. \\
\hline $\begin{array}{l}\text { Moving forward, do you think LEED is } \\
\text { going to be the new benchmark (i.e. the } \\
\text { new A class)? }\end{array}$ & No. & Yes. & Yes. \\
\hline $\begin{array}{l}\text { Could a building built in compliance } \\
\text { with LEED, but without the certification } \\
\text { (label), achieve the same returns as a } \\
\text { LEED certified (labelled) building? }\end{array}$ & Yes. & Yes. & Yes. \\
\hline $\begin{array}{l}\text { Will LEED certification help attract } \\
\text { more potential purchasers/tenants? }\end{array}$ & Yes. & Yes. & Yes. \\
\hline
\end{tabular}

\section{Discussion of Interview Responses}

Does LEED certification currently have a significant impact on achievable gross rent?

An important point to make with regard to this question was that it referred to achievable gross rent rather than net asking rent (the dependent variable in the model). This became the focus of question responses as interviewees sought to distinguish the effects of LEED certification from those of operating costs on rents. As LEED buildings tend to have lower operating costs, landlords will increase the net rent portion of the formula to keep their properties comparable with the market on a gross rent basis. With this in mind, although potential savings in operating expenses allow for possible

\footnotetext{
${ }^{27}$ See Appendix D for a complete transcription of interviews.
} 
increases in net asking rents, each of the parties interviewed did not see LEED as having a significant impact on achievable gross rent.

Moving forward, do you think LEED is going to be the new benchmark (i.e. the new $A$ class)?

Interviewee 1 differed from the others in their response to this question. The reason for the difference of opinion was that interviewee 1 approached the question from the standpoint of what tenants value, gross rent. And seeing as LEED is not considered to have a significant impact on gross rent, it is not likely to become a factor in developing a new building standard. The second interviewee approached the question from the standpoint of what valuation professional consider during the property appraisal process, noting that there will a factor built into appraisal methodology that gives green buildings more value because they last longer. Finally, the third interviewee noted that when they first decided to pursue LEED certification it was a marketing advantage, while now it is becoming the standard. So based on the interviews, when trying to determine whether LEED is going to become the new benchmark (standard) it is important to ask a second question...to whom? From the interviews, it seems that LEED is becoming a standard in Toronto for Landlords/Developers and Valuation professional, while tenants are predominantly concerned with what they will be paying in gross rent, regardless of what portion of their rent comes from operating expenses and what portion is net asking rent.

Could a building built in compliance with LEED, but without the certification (label), achieve the same results as a LEED certified (labelled) building? 
All interviewees felt that a building that was not LEED labelled could achieve the same returns as an otherwise comparable LEED labelled building. This unanimous opinion seemed to have stemmed from the point that the returns currently generated from LEED buildings stem from a reduction in operating costs.

Will LEED certification help attract more potential purchasers/tenants?

All of the interviewees were of the mind that LEED certification will help attract more potential purchasers/tenants, although the consensus seems to be that those potential tenants are not likely to be willing to pay a premium on a gross rent basis for a building that is LEED certified.

General conclusions derived from interviews:

All three interviewees had similar responses with respect to their views on LEED certification's impact on achievable rent, ability to let, and the attitudes of prospective tenants. The insight gleaned from the interviews lends to the idea that, although the current study did not find LEED certification to have a statistically significant impact on net asking rent, as markets continue to evolve and stakeholders place an increasing amount of importance on sustainability, we are likely to see LEED certification become a more significant factor in the determination of office rents. In addition, as more LEED buildings come onto the market, it will allow for studies with a larger sample size, allowing for inclusion of coefficients with more subtle impacts into the model, thereby making it possible that future studies with larger sample sizes may find LEED a significant contributor to property value. 


\section{Conclusions}

\section{Contributions}

This study contributes to the literature by assessing whether LEED certification has a significant impact on determining net asking rents in Canada's largest office market (Toronto, Ontario), an area where the financial benefit of obtaining LEED certification has not attracted sufficient research attention. In the current literature, the main focus has been on markets outside of Canada, but much less attention has been paid to what extent the Canadian office market values LEED certification. Although this study did not find LEED certification to be statistically significant in explaining the variance in net asking rents, this study can be helpful in setting parameters for more advanced research on the impact that LEED certification has on net asking rents and other measures of property value. Given the high rate of adoption of LEED certification by landlords in markets across North America, this will continue to be a promising area of research

The results of the study have shown that LEED certification has had no impact on the market value of the sample of office buildings in Toronto. This is a surprising result, given the growth in the number of LEED buildings in Canada, but interviews with three senior executives in the industry have helped to explain it. One might think of that impact as a wave which is coming to the commercial market, but has not yet arrived. This is a hypothesis for future work that can be tested by repeating this study in future years, using the present approach as the basis. 


\section{Implications for practitioners}

This study provides directions for managerial practice. The study presents two main implications for landlords/developers that may be considering LEED certification for office buildings in the downtown Toronto area. First, given that the study did not find LEED certification significant in explaining the variation in net asking rents, it follows that practitioners looking to maximize building returns should be cautious in subscribing to LEED if the costs associated with achieving certification are significant.

Second, if the financial draw for practitioners is associated with a reduction in operating expenses and not the marketing impact of a LEED label, then these building improvements can still be achieved without requiring the payment of various fees associated with the certification process. From this standpoint it may be beneficial for practitioners to consider investing in building characteristics that serve to reduce operating expenses and/or increase the building class rating, as both of these building attributes have been shown to be more significant in explaining the variance in office rents than LEED certification. However, interviews suggest that benefits derived from using LEED as a guide to building "green", as well as a method of providing proof to prospective tenants, are other benefits derived from LEED that could not be had otherwise.

\section{Limitations and directions for future studies}

Despite the efforts made to ensure the best possible design for the study, there are limitations that should be acknowledged. First, due to the confidential nature of 
information related to tenant lease contracts, information related to actual rent per square foot paid and tenant inducements were not included in this study. Instead, average net asking rental rates for each building were used as a proxy. If possible, future studies should look to include information related to actual transacted leases. This would allow for the impact of tenant inducements ${ }^{28}$ and actual transacted rent to be used, providing a more accurate depiction of those factors having a significant impact on actual returns to landlords. The use of actual transaction information may also have an effect on LEED certification's inclusion into a model seeking to explain the variance in actual transacted rents.

A second limitation of this study is the inability to generalize study results to other markets. This study was not intended to generalize findings to other real estate markets, but rather to gain insights on the influence of LEED certification within the market studied. Future studies may look to expand the study area beyond the boundaries of Toronto or increase the number of Toronto submarkets included in an effort to determine if LEED's impact on rents changes based on market/submarket characteristics.

A third limitation of this study is that, due to the relative infancy of the LEED movement in Canada, it was only able to provide a 'snapshot' of the impact (or lack thereof) that LEED certification has on net asking rent. As this movement matures, longitudinal studies related to the change in costs and benefits over time and over varying economic conditions would prove valuable. Such studies would not only provide a

\footnotetext{
${ }^{28}$ Tenant Inducements may include such things as free rent periods, modification of the space according to tenant specifications, or any other form of incentive a landlord may offer a prospective tenant in efforts to let space.
} 
historical trend analysis, but may also provide key stakeholders some foresight as to issues and opportunities that may become factors in the near and distant future.

The infancy of the LEED movement in Canada was also cause for the limited number of LEED certified buildings being available for inclusion in this study, resulting in a sample size that would have only allowed for the inclusion of those variables thought to have a medium to large effect size on net asking rents. As more LEED buildings enter the market, future studies will be able to increase sample size to a level that would allow for the detection of a smaller effect size on net asking rent and other measures of value.

Finally, it is important to note that this study does not provide an assessment of the incentives provided by various regions in an effort to encourage responsible property development. As the goal of this study was to assess the impact of LEED certification on net asking rents, future studies may look to undertake a complete cost/benefit analysis that takes into account incentives to LEED certification not resulting from market value impacts. Studies of this nature would also allow for the identification of regions considered most encouraging of responsible property development, and perhaps even more importantly, would provide other regions with information on what initiatives have been successfully adopted elsewhere that may be applied to their own. 


\section{References}

Bansal, P. \& Hunter, T. (2003). Strategic explanations for the early adoption of ISO 14001. Journal of Business Ethics, 46, 289-299

Bollinger, C. R., Ihlanfeldt, K. R., \& Bowes, D. R. (1998). Spatial variation in office rents within the atlanta region. Urban Studies, 35(7), 1097-1118.

Bowman, R., \& Wills, J. (2008). Valuing green. how green buildings affect property value and getting the valuation method right. Melbourne, Australia: Australian Green Building Council.

Boyd, T. (2005). Can we access the worth of environmental and social characteristics in investment property? Unpublished manuscript.

Broughton, J. (2006). Green building costs, saving and value. Environmental Design \& Construction Magazine, , 22-24.

Bruntland, G. (1987). Our common future. world commission on environment and development. New York: Oxford University Press.

Burnett, J. (2007). City buildings - eco-labels and shades of green! Landscape and Urban Planner, 8(1), 29-38.

Canada Green Building Council, March 20, 2011, www.cagbc.org

Canada's national climate change business plan 2002(2002).

Cannaday, R. \& Kang, H. (1984). Estimation of market rent for office space. Real Estate Appraiser and Analyst, 50, 67-72

Carson, R. (1962). Silent spring. Boston: Houghton Mifflin.

Chan, E.S.W. \& Wong, S.C.K. (2004). Motivations for ISO 14001 in the Hotel Industry. Tourism Management, 27, 481-492 
City of Toronto, March 20, 2011, http://www.toronto.ca/invest-in-toronto/real_estate.htm

Clap, J. (1980). The intrametropolitan location of office activities. Journal of Regional Science, 20, 387-399

Clark, P. (2007). Property bosses search for sustainable evidence. Building,

Cole, R. (1998). Emerging trends in building environmental assessment methods. Building Research and Information, 26(1), 3-16.

Committing and Engaging United Nations Environment Programme Finance Initiative (UNEP FI).

Crawley, D., \&Aho, I. (1999). Building environmental assessment methods: Applications and development trends. Building Research and Information, 27(4-5), 300-308.

De Francesco, A., \& Levy, D. (2008). The impact of sustainability in the investment environment: A case study of australia. London: RICS.

Delmas, M. (2000). Stakeholders and Competitive Advantage: The Case of ISO 14001. Production and Operation Management, 10(3), 343-358

Dunse, N. \& Jones, C. (1998). A hedonic price model of office rents. Journal of Property Valuation \& Investment. 16(3), 297-312.

Du Plessis, C. (2002). Agenda 21 for sustainable construction in developing countries: A discussion document Report for CIB and UNEP-IETC.

Edwards, B. (2003). Green buildings pay. New York: Spon Press.

Eichholtz, P., Kok, N., \& Quigley, J. M. (2009). Doing well by doing good? green office buildings. California: University of Berkley: Institute of Business and Economics Research.

Elkington, J. (2004). Enter the triple bottom line. The Triple Bottom Line: Does it all Add Up?, pp. 1-16.

Ellison, L., Sayce, S., \& Smith, J. (2007). Socially responsible property investment: Quantifying the relationship between sustainability and investment property worth. Journal of Property Research, 24(3), 191-219.

Ellison, L., \&Sayce, S. (2006). The sustainable property appraisal project

Fisk, W. J. (2000). Health and productivity gains from better indoor environments and their implications for the U.S. department of energy. E-Vision 2000 Conference, 
Fryxell, G.E. \& Szeto, A. (2002). The influence of motivations for seeking ISO 14001 certification: an empirical study of ISO 14001 certified facilities in Hong Kong. Journal of Environmental Management, 65, 223-238

Fuerst, F., \& McAllister, P. (2009). An investigation of the effect of eco-labeling on office occupancy rates. Unpublished manuscript.

Gilbertson, B., \& Preston, D. (2005). A vision for valuation. Journal of Property Investment and Finance, 23(2), 123-140.

Green building incentives that work: A look at how local governments are incentivizing green development(2009). . Herndon, VA: The National Association of Industrial and Office Properties Research Foundation. Retrieved from http://www.naiop.org/foundation/greenincentives.pdf

Green property: Does it pay?(2005). . Sydney: Merrill Lynch.

Green value. green buildings, growing assets(2005). London: RICS. Retrieved from http://www.bluewildernessgroup.com/index.php?action $=$ display\&cat $=43 \&$ doc $=$ gre envaluesreport_1.pdf

Greening UK cities' buildings - improvising the energy efficiency of our offices, shops and factories(2008). All Party Urban Development Group.

Guertler, P., Pett, J., \& Kaplan, Z. (2005). "Valuing low energy offices: The essential step for the success of the energy performance of buildings directive". Proceedings of the 2005 ECEEE Summer Study on Energy Efficiency, European Council for an Energy-Efficient Economy, Paris, pp. 295-305.

Gva, G. (2007). Towards sustainable offices. Research Bulletin,

Hagart, G., \&Knoepfel, I. (2008). The value of environmental and social issues to real estate investors. Stockholm: Mistra - The Foundation for Strategic Environmental Research.

Hebb, T., Hamilton, A., \&Hachigian, H. (2009). Responsible property investing in Canada: Factoring both environmental and social impacts in the Canadian real estate market. Ottawa, ON: Carleton Centre for Community Innovation.

Heisterkamp, M. (2009). State of the green commerialral estate market. Environmental Design \& Construction, 12(7), 68.

Heschong, L. (2003). Windows and offices: A study of worker performance and the indoor environment. HeschongMahone Group, Inc. 
Hill, R. C., \& Bowen, P. A. (1997). Sustainable construction: Principles and a framework for attainment. Construction Management and Economics, 15(3), 223-239.

Hinnells, M., Bright, S., Langley, A., Woodford, L., Schiellerup, P., \&Hinnells, M. (2008). The greening of commercial leases. Journal of Property Investment and Finance, 26(6), 541-551.

Hough, D. \& Kratz, C. (1983). Can "good" architecture meet the market test? Estates Gazette, Issue 9283, pp.144-45.

REED, R.G. \& Wilkinson, S.J. (2005). The increasing importance of sustainability for building ownership. Journal of Corporate Real Estate, 7(4), 339-351.

International Valuation Standards (2007). (Eighth ed.) International Valuation Standards Committee.

International Organization for Standardization. Press Release. June 5, 2011. http://www.iso.org/iso/pressrelease.htm?refid=Ref1363

Jayne, M., \& Skerrat, G. (2003). The requirements of ethical fund managers and property investment. Property Management, 21(2), 136-152.

Jiang, R.J. \& Bansal, P. (2003). Seeing the NEED for ISO 14001. Journal of Management Studies, 40(4), 1047-1067

Kats, G., Alevantis, L., Berman, A., Mills, E., \& Perlman, J. (2003). The costs and financial benefits of green buildings. Sustainable Building Task Force,

Katz, A. (2008). Green building returns outweigh costs. Retrieved June 1, 2010, from http://www.edcmag.com/articles/green-building-returns-outweigh-costs

Keeping, M. (2000). What about demand? do investors want 'sustainable buildings'? The Cutting Edge 2000, Oxford.

Lam, P. T. I., Chan, E. H. W., Poon, C. S., Chau, C. K., \& Chun, K. P. (2010). Factors affecting the implementation of green specifications in construction. Journal of Environmental Management, 91(3), 654-661.

Lam, P. T. I., Kumaraswamy, M. M., \&Ng, T. S. T. (2007). An international treatise on construction specifications. Journal of Professional Issues in Engineering Education and Practice, 133(3), 229-237.

Lambersky, S. \& D’Souza, W., DTZ Barnicke, April, 2011, http://www.dtzbarnicke.com/client/JJB/JJB_LP4W_LND_WebStation.nsf/resource s/2011+Market+Reports/\$file/GTA Q1-2011 Office.pdf 
Landman, M. (1999). Breaking through the barriers to sustainable building: Insights from professionals on government initiatives to promote environmentally sound practices. (MA, Tufts University).

Langdon, D. (2007). The cost and benefit of achieving green buildings. London: Davis Langdon.

Liberal Party of Canada. (2008). The green shift: Building a Canadian economy for the 21st century. Ottawa, ON, Canada: Liberal Party of Canada.

Lippiatt, B. C. (1999). Selecting cost-effective green building products: BEES approach. Journal of Construction Engineering and Management, 125(6), 448-455.

Loftness, V., Hartkopf, V., Gurtekin, B., Hua, Y., Qu, M., \& Snyder, M. (2005). Building investment decision support. American Institute of Architects 2005 Report on University Research.

Lorenz, D., \& Lutzkendorf, T. (2008). Next generation decision support instruments for the property industry - understanding the financial implications of sustainable building. World Sustainable Building Conference (SB08), Melbourne, Australia.

Lorenz, D., \& Lützkendorf, T. (2008). Sustainability in property valuation: Theory and practice. Journal of Property Investment and Finance, 26(6), 482-521.

Lorenz, D., Lutzkendorf, T., \& Panek, A. (2005). Sustainable construction in Central/Eastern europe: Implications from SB04 in Warsaw. Building Research and Information, 33(5), 416-427.

Lucuik, M., Trusty, W., Larsson, N., \& Charette, R. (2005). A business case for green buildings in canada. Ottawa, ON: Morrison Hershfield.

Madew, R. (2006). The dollars and sense of green buildings. Sydney: The Green Building Council of Australia.

Matar, M. M. (2007). An integration framework for sustainable construction. (MSc, Cairo University).

Matar, M. M., Georgy, M. E., \& Ibrahim, M. E. (2004). Towards a more applicable set of sustainable construction practices. International Conference: Future Vision and Challenges for Urban Development, Cairo, Egypt. 1-12.

Matar, M. M., Georgy, M. E., \& Ibrahim, M. E. (2008). Sustainable construction management: Introduction of the operational context space (OCS). Construction Management and Economics, 26(3), 261-275. 
Matthiessen, L. F., \& Morris, P. (2004). Costing green: A comprehensive cost database and budgeting methodologyDavis Langdon.

McNamara, P. (2008, Will greener buildings bring bigger profits? Professional Investor, , 41-43.

Miller, N., Spivey, J., \& Florance, A. (2008). Does green pay off? Journal of Real Estate Portfolio Management, 14(4), 385-399.

Millington, A. F. (2000). An introduction to property valuation (5th ed.). London: Estates Gazette.

Morrow, D. \& Rondinelli, D. (2002). Adopting Corporate Environmental Management Systems: Motivations and Results of ISO 14001 and EMAS Certification. European Management Journal, Vol. 20, No. 2, pp. 159-171

Morton, S. (2002). Business case for green design. Building Operating Management,

Muldavin, S. (2008). Quantifying "green" value: Assessing the applicability of the CoStar studies. San Rafael: The Muldavin Company.

Myers, G., Reed, R., \& Robinson, J. (2008). Investor perception of the business case for sustainable office buildings: Evidence from New Zealand. 14th Annual Pacific Rim Real Estate Society Conference, Kuala Lumpur, Malaysia.

Neumayer, E. \& Perkins, R. (2004). What explains the uneven take-up of ISO 14001 at the global level? A panel-data analysis. Environment and Planning A, 36, 823-839

Parnell, P. (2005). Sustainability: What's all the fuss about...? RICS Annual Conference, Loughborough University, Loughborough.

Patton, M.Q. (2002). Qualitative research and evaluative methods, 3ed edition. Thousand Oaks, CA: Sage.

Pearce, A. R., \&Vanegas, J. A. (2002). Defining sustainability for built environment systems: An operational framework. International Journal of Environmental Technology and Management, 2(1-3), 94-113.

Persram, S., Lucuik, M., \& Larsson, N. (2007). Marketing green buildings to owners of leased properties. Green Building Council of Canada,

Pivo, G. (2005). Is there a future for socially responsible property investment? Real Estate Issues, Vol. 30, No.1, pp. 16-26. 
Pivo, G. (2008). Exploring responsible property investing: A survey of american executives. Corporate Social Responsibility and Environmental Management, 15(4), 235-248.

Pivo, G. (2008). Responsible property investing: What the leaders are doing. Journal of Property Investment and Finance, 26(6), 562-576.

Pivo, G. (2008). Responsible property investment criteria developed using the delphi method. Building Research and Information, 36(1), 20-36.

Pivo, G. (2009). Social and environmental metrics for US real estate portfolios: Sources of data and aggregation methods. Journal of Property Investment and Finance, 27(5), 481-510.

Pivo, G., \& McNamara, P. (2005). Responsible property investing. International Real Estate Review, 8(1), 128-143.

Potoski, M. \& Prakash, A. (2004). Regulatory Convergence in Nongovernmental Regimes? Cross-National Adoption of ISO 14001 Certifications. The Journal of Politics, Vol. 66, No. 3, pp. 885-905

Potoski, M. \& Prakash, A. (2005). Green Clubs and Voluntary Governance: ISO 14001 and Firms' Regulatory Compliance. American Journal of Political Science, Vol. 49, No. 2, pp. 235-248

Rapson, D., Shiers, D., Roberts, C., \& Keeping, M. (2007). Socially responsible property investment (SRPI): An analysis of the relationship between equities SRI and UK property investment activities. Journal of Property Investment and Finance, 25(4), 342-358.

Reed, R. (2009). Encouraging the uptake of sustainable buildings and the role of the property valuer. London: RICS.

Reed, R., \& Wilkinson, S. J. (2005). The increasing importance of sustainability for building ownership. Journal of Corporate Real Estate, 7(4), 339-351.

Robèrt, K. -. (2000). Tools and concepts for sustainable development, how do they relate to a general framework for sustainable development, and to each other? Journal of Cleaner Production, 8(3), 243-254.

Robèrt, K. -., Schmidt-Bleek, B., Aloisi de Larderel, J., Basile, G., Jansen, J. L., R. Keuhr, et al. (2002). Strategic sustainable development - selection, design and synergies of applied tools. Journal of Cleaner Production, 10, 197-214. 
Robinson, J. (2005). Property valuation and analysis applied to environmentally sustainable development. The Dollars and Sense of Green Buildings: Building the Business Case for Green Commercial Buildings in Australia,

Rogers, E.M. (1963). Diffusion of Innovations. New York: Free Press, p. 247

Rondinelli, D. \&Vastag, G. (2000). Panacea, Common Sence, or Just a Label? The Value of ISO 14001 Environmental Management Systems. European Management Journal, Vol. 18, No. 5, pp. 499-510

Roper, K. O., \& Beard, J. L. (2006). Justifying sustainable buildings - championing green operations. Journal of Corporate Real Estate, 8(2), 91-103.

Rosen, S. (1974). Hedonic prices and implicit markets: product differentiation in pure competition. Journal of Political Economy, 82, 34-55.

Sayce, S., Ellison, L., \& Parnell, P. (2007). Understanding investment drivers for UK sustainable property. Building Research and Information, 35(6), 629-643.

Scheuer, C. W., \&Keoleian, G. A. (2002). Evaluation of LEED using life cycle assessment methods. Gaithersburg, MD, USA: National Institute of Standards and Technology (NIST).

Schneider, K. (2002, December 27, 2002). A new green coat for an old grey factory. Great Lakes Bulletin News Service,

Schumacher, E. F. (1974). Small is beautiful: A study of economics as if people mattered. London: Sphere Books.

St. Lawrence, S. (2004). Review of the UK corporate real-estate market with regard to availability of environmentally and socially responsible office buildings. Journal of Corporate Real Estate, 6(2), 149-161.

Stern, N. (2007). The economics of climate change: The stern review. Cambridge, UK: Cambridge University Press.

Sustainability: Towards sustainable offices(2007). . London: GVA Grimley.

Sustainable investment survey: From green to gold(2007). . London: GVA Grimley.

Turner, C., \& Frankel, M. (2008). Energy performance of LEED for new construction buildings. Washington, DC: U.S. Green Building Council.

U.S. Green Building Council, March 20, 2011, www.usgbc.org 
Vanegas, J. A., \& Pearce, A. R. (2000). Drivers for change: An organizational perspective on sustainable construction. Construction congress VI (pp. 406-415). Orlando, Florida, USA: ASCE.

Warren-Myers, G., Bienert, S., \& Warren, C. (2009). Valuation and sustainability are rating tools enough? Paper presented at the European Real Estate Society Conference, Stockholm, Sweden.

Wheaton, W. C., \&Torto, R. G. (1994). Office rent indices and their behavior over time. Journal of Urban Economics, 35(2), 121-139.

Why all the fuss? building sustainability and rating systems across Australia and New Zealand (2008). . London: DTZ Research.

Wiley, J. A., Benefield, J. D., \& Johnson, K. H. (2008). Green design and the market for commercial office space. Journal of Real Estate Finance and Economics, , 1-16.

\section{Appendix}

\section{Appendix A: Membership Growth in Canadian Green Building Council}

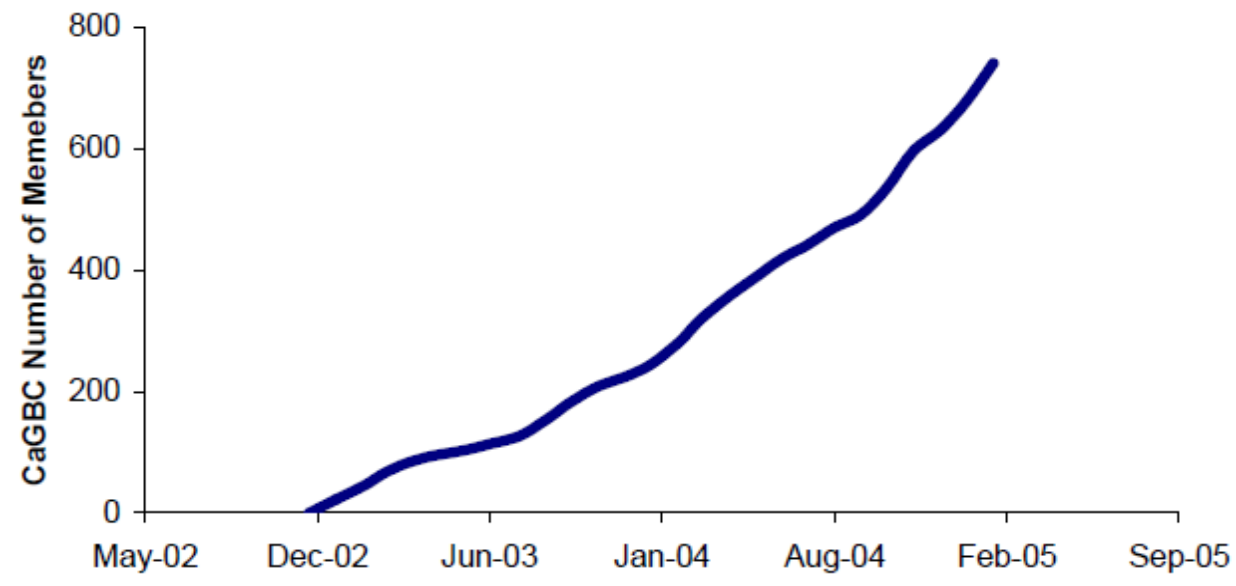

Source(35 Lucuik,M. 2005) 


\section{Appendix B: Membership Growth in U.S. Green Building Council}

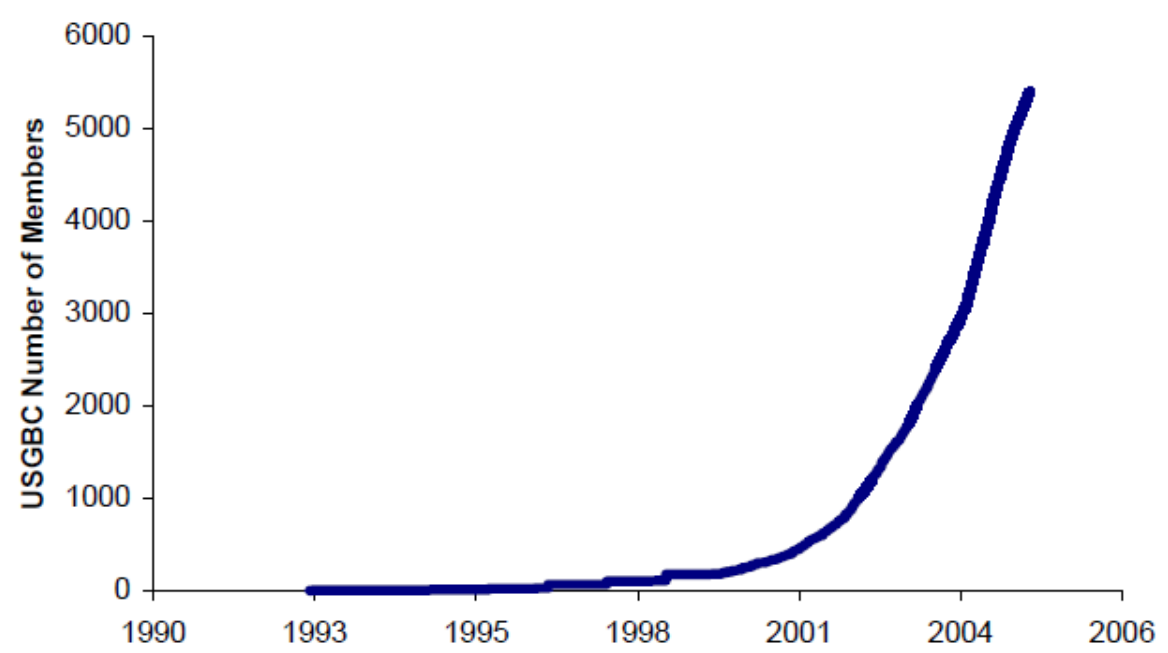

Source :(35 Lucuik,M. 2005)

\section{Appendix C: "The Vicious Circle of Blame"}

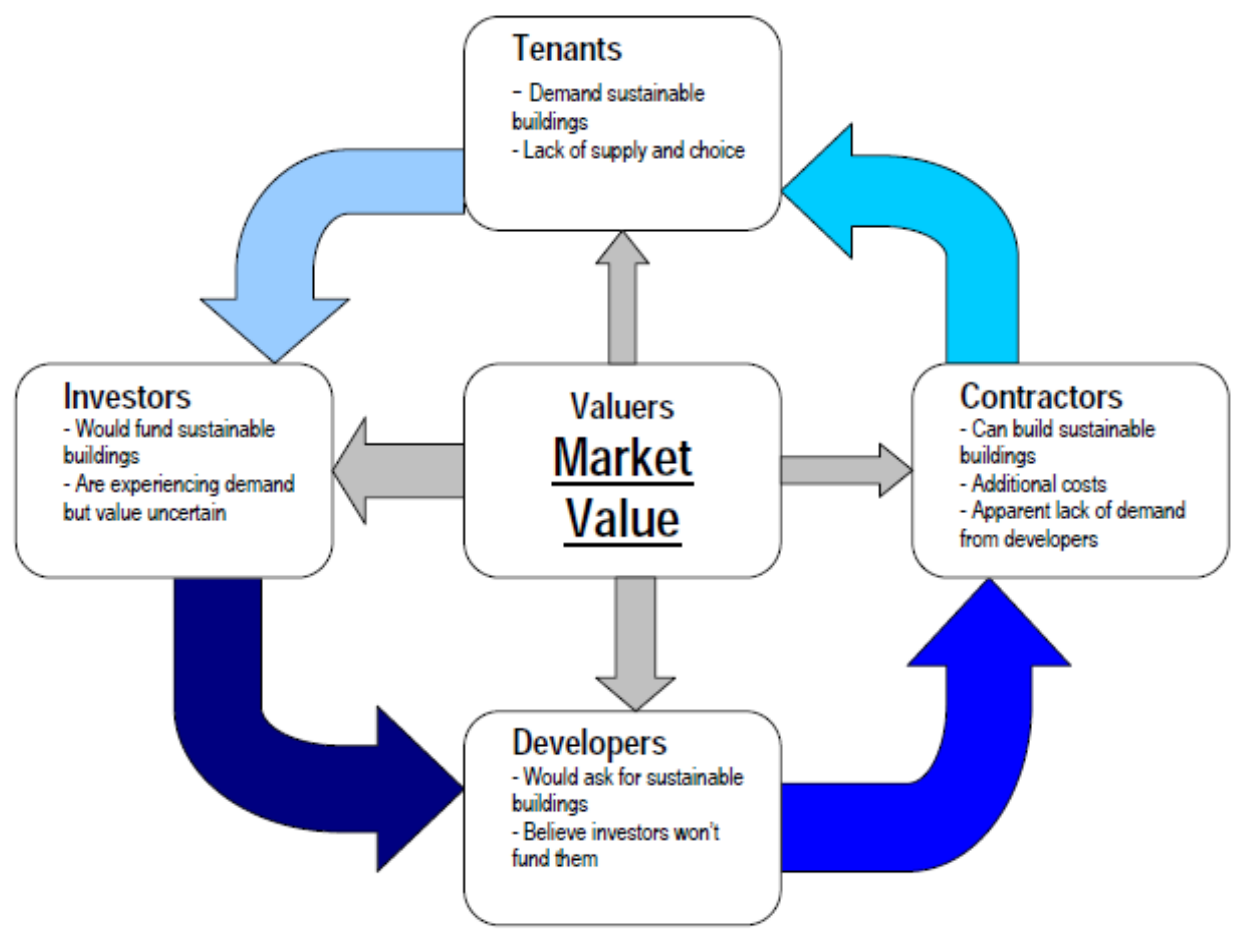

Source: (Myers, 2008) 
"The Vicious Circle of Blame" depicted above, is a representation of the barriers faced by key stakeholder groups in the adoption of sustainable building practices such as LEED resulting from their relationship with/ dependence on other stakeholders involved in the market adoption of sustainable building practices. The above diagram depicts the following:

- Developers blame investors. They would ask for/develop sustainable buildings, but believe investors won't fund them.

- Contractors blame developers. They can build sustainable buildings, but feel there is a lack of demand from developers, especially if there are additional construction costs involved.

- Tenants blame contractors. They would occupy these buildings if there were more supply and choice provided by the contractors who build the buildings.

- Investors are blaming tenants. They would fund sustainable buildings, especially given the expressed demand from tenants, but are concerned about tenant's willingness to pay a premium that would justify the added investment in making a building more sustainable.

- Finally, valuation professionals (valuers) need to be shown that the market values sustainable building characteristics before that value can be represented in the valuation process.

\section{Appendix D: Transcription of Interviews}

Interview 1:

Interviewee Profile: Interviewee 1 serves as Vice President to one of Canada's largest

Landlords/Developers. In that role he is responsible for the origination and execution of

office, industrial, and land transactions, together with major property portfolios across

Canada.

The Interview:

In your experience, do you feel that LEED certification has a significant impact on achievable net rents? 
Having a LEED building certainly does cut down the operating expenses, allowing you to achieve a greater net rent while still remaining competitive with other buildings on a gross basis. You might be higher on a net basis, but you'll be lower on a gross basis because you are able to achieve some net savings that you can pass on to the tenant.

But above and beyond that, take 18 York Street for example. That is a building that GWL is building on behalf of BCIMC, and their big tenant they have right now is PWC. When these guys pulled the trigger it was in 2008 at a point when the market had already shifted down into tenant favour. Nobody was leasing space. There was a credit crunch. Investment transactions were few and far between and yet BCIMC still went ahead to develop that building. And the reason why was because they wanted to be able to say that they owned a downtown building that was LEED certified. Their thought is that large tenants on a go forward basis - banks, insurance firms, law firms will make it a requirement. That any space that they lease has to be in a LEED building that is reflective of their overall objective with respect to the environment in their business plan model. So yeah, I think that over time you are going to see that rents are only going to go in one direction for LEED buildings.

\section{Do you think that LEED buildings are going to be considered the new A class?}

Tenants are only concerned with the gross rents. They do not care what the net rent is, they do not really care what the taxes and operating costs are. They want to know what their gross rents are. So as long as their gross rents are competitive to class A buildings and they know that their carbon footprint is less and they are doing a good thing for the environment they'll go there. Although some tenants will make that a requirement and 
will pay more just to be in that building. But, if you are able to track a comparison between LEED buildings and comparable class A buildings, I think you are going to see at least a $\$ 2-3 /$ sqft savings, and I think that you will be able to make up for that in net rent.

\section{Above and beyond additional rent savings, do you think that from a marketing perspective, over the long term, LEED buildings will be able to achieve significantly higher rents?}

No. There is an inherent value that you are adding. From a liquidity standpoint, let's say, if I am the broker and I have got two buildings I can sell. One is the triple A office building downtown, and the other is similar building that is LEED certified I believe the LEED building will attract more buyers because people are feeling conscious. Am I going to get more value for it? No, I don't think so.

\section{Do you think that from a sales standpoint LEED certification is going to help you attract more potential purchasers?}

Yes. I believe that, but I do not think that will necessarily translate into more value. And that relates back to your earlier question where you asked me if I thought a tenant would be willing to pay more for a LEED building, and I said no. And the reason I say no is that tenants have their own going concerns that they are worried about and rent represents a really big part of their obligations, their costs, especially if you are renting four floors of downtown office space and frankly they are driven by the bottom line. Yeah, you do have some big companies like maybe PWC that were motivated by the fact that it was a LEED building, but I think it was just that they were the lead tenant in that project, so 
undoubtedly GWL gave them a bit of a concession to get them in and then they could attract others.

If I had a B class building that I was planning on retrofitting to bring it up to date with the aim of reducing my operating costs in an effort to increase my achievable net rent, do you think I should undertake to have the building LEED certified and pay the additional costs associated with that? Or do you say if you can reduce additional costs for your prospective tenants then that is good enough?

I would say, and its unfortunate, its probably the latter. We are selling a building right now where they have BOMA BEST certification, where they have acknowledged that they have been able to reduce operating costs through efficiencies. It is a class A building and it is in the suburbs, but at the end of the day if they were able to attain LEED status I don't think that would increase their occupancy, or necessarily translate into more net rents, and its unfortunate, but I really don't think that is the case.

\section{Interview 2:}

Interviewee Profile: Interviewee 2 serves as Senior Vice President for one of Canada's largest Landlords/Developers. In that role he is involved in informing the decisionmaking that provides the company with strategic direction.

The Interview: 


\section{I understand you have a building in downtown Toronto that you are getting LEED certified, why did you decide to prescribe to LEED certification, and why this building specifically?}

It goes back to Fall of 2005, while we had the site under contract and we closed in December of 2005. Imagine a board meeting where I was making a presentation to three owners in September. Three different owners: The first one was the Menkes Family, who had a 20 percent interest in the property. Their comment was, "we have no clue what LEED is", this was before LEED existed in Canada, "we understand in terms of the world sustainability is going to be necessary. We are responsible developers, so if you think it is the right thing to do then it will be one of our specifications and we will figure it out as we go." That's 20 percent; Then the hospitals of Ontario Pension Plan, who owned 50 percent. They say, “we also don't know what it is because we haven't seen anything, no building exists in Canada. But we, representing our pensioners, all 40,000 of them, wish to respect sustainability in everything we do." That's 50 percent; The Harvard endowment fund, who represented 20 percent, said, "if this is not a LEED building we will not invest, simply because we are setting the standards in terms of regulations of the sort world wide. Our people are. Our graduates are. And sustainability is a must." That is where it all started. So we started as responsible citizens, and then as investors, and then as owners of real estate in Canada. The LEED manuals didn't even hit the table until 2007. So we were ahead of the curve, and in hindsight every single tenant who walked into the building asked about our sustainability platform. Every single tenant who walked into the building wanted a green platform. 
Seeing the success you have achieved with this building, are their plans for the certification of others?

We have another office development downtown and the building will be somewhere in the 900,000 sqare feet range and we too will be LEED Gold core and shell. Moving forward it is simply the only standard we have.

Are you only looking to certify new developments, or are you looking at retrofits as well?

In terms of existing buildings, we have numerous applications in for LEED on a number of our office complexes. No industrial.

\section{Is there a reason why you are not for industrial but are for office buildings?}

The tenants are more interested in it. And on industrial it is next to impossible to achieve on an existing industrial space. You can achieve it moving forward with a new LEED development, but moving backwards, no.

Comparing you LEED certified building to others in your portfolio and others you compete with in that market, do you think that the LEED certification has been a factor in achievable gross rent.

Zero. Now let's qualify that. There is no history. Everything we put into 25 York was a projection. People had to believe it was going to happen. I had no ability to get any higher rent than another office tower in downtown Toronto which doesn't have it, because there was no proof. Many a time tenants ask, "Well, how do you know?" and we would reply, "Because our engineers tell us." And they reply, "So! You know the Prime 
Minister of Canada tells us we are going to be debt free too...show me!” Ask that question in 5-10 years. Then the green buildings will stand out.

\section{So do you think that moving forward LEED is going to be the new standard?}

Definitely! As markets go forward. And, from an appraisal point of view, there will be a factor built into all appraisals which give green buildings more value because they will last longer.

\section{What do you think the impact of LEED certification will be as markets fluctuate?}

If it is a tenant's market, LEED will win first. If it is a landlord's market, nobody gives a shit.

\section{Additional discussion.}

Every single tenant that moved into our LEED building insisted they build to LEED standard. When asked: are you going to certify? One tenant said that, according to their corporate platform, they wished to be one of the top 50 sustainable companies in the world. So they went through a certification process. Every other tenant said, "I don't need a certification, I don't need to pay for all that bullshit. I get nothing for the certificate on the wall. I just want to know myself I did the right thing. 
Apart from the reduction in operating costs, do you find any value in the LEED label itself?

Not today.

So if you had an otherwise comparable property, are you saying that you would not bother getting the building LEED certified?

You asked me do I perceive any value! Me the landlord. Look at it from the tenant's point of view. Not one tenant believes one landlord! Therefore, I have to get a certification by a third party in order for the tenant to believe me. The tenants perceive value in the buildings. Long term, LEED counts. It may not be called LEED in 10 or 15 years, but sustainability counts. And what is happening with these buildings is that, over and over, the manufacturers of materials and equipment are pursuing certification themselves because they are listening to the politicians saying that it is coming, we have to save the world. More importantly they are listening to their kids.

On top of that, every single pension plan, The CASE, BOMERS, Teachers Pension Plan of Ontario, BCIMC, IMCO. They have said, they have decreed, they have policies, "if we are developing new office buildings they shall be green." Representing their pensioners. Their pensioners are average everyday people. It started with BCIMC out of British Columbia, as it should, that is where the green movement started.

\section{Interview 3}


Interviewee Profile: Interviewee 3 serves as the National Director of Sustainability and Energy Management for one of Canada's largest Landlords/Developers. In that role he informs company decision-making related to making the company's more environmentally responsible and energy efficient.

The Interview:

\section{Do you have any LEED certified buildings.}

Yes we do.

\section{Are they new builds or retrofits?}

New builds, but we are also going to have a couple of retrofits coming up this year.

With respect to the buildings that you already have certified and the ones that are soon to be certified, why did you decide to certify these buildings?

Two reasons. At the time LEED was beginning to be considered a competitive advantage, and for the buildings we decided to have certified it was not a complicated process and the cost premium was not that significant. 
When you talk about competitive advantage, are you talking about making it easier to lease the space thereby reducing vacancy, or are you talking about an ability to achieve higher gross rents.

When we develop the building pro forma, we put together the project and we start marketing it so that the building is already tenanted by the time it is delivered. So as we were marketing the property some of our clients liked the fact that it was LEED certified. They see it through two perspectives: One is the PR. Marketing wise they see it as something they can make use of and portray their companies as more environmentally conscious with a higher CSR status.

The second is that there is a higher level of predictability when it comes to utilities. So they know that if they are coming into a certified building there are higher environmental and ethical standards, and that the building is going to perform closer to what they have budgeted for in future years. So the level of certainty is important, especially for those companies where real estate is a big component of their finances.

\section{Did LEED certification meet your expectations in terms of competitive advantage}

\section{for your buildings?}

Yes. Also, some of the tenants in our non-LEED certified buildings are looking for LEED certified space.

\section{Are you noticing LEED as a factor for other potential tenants?}


Yes. When we are building a property, potential tenants will ask, "do you guys plan on building it to LEED certified standards", and we say "yes", and that becomes part of the negotiation. And the big thing is that we wouldn't do it any other way. We wouldn't do it any other way because it is now the market expectation to have your building LEED certified.

Are you saying that from now on when you build it is going to be LEED certified?

Yes. Pretty much. When we had decided to certify one of our buildings about 3 or 4 years ago it was a marketing advantage, while now it is becoming the standard. And I am not sure how far down the road it is going to be detrimental in some cases where we will have to LEED certify.

\section{Do you think that you could have built to LEED certification standards without getting the buildings certified and achieved the same results?}

Yes, however collecting the data and following the protocols is not as efficient if you do not have to comply with a certification. The moment you say that we need to do this to get the certification things start to happen faster. Even if you don't have the certification you should be able to do the work to that standard, but at the end it doesn't seem to work that way. The certification process acts as a guide throughout the development process.

\section{Do you plan on retrofitting all your buildings as well to be LEED certified?}


Not all of them. There are some buildings where it makes a lot of sense, where we have tenants that want to be in a certified building, some buildings where we have challenges with utilities, and so on. But there are properties where there is no need for it. It could be because they are in a very strong market, because we have long-term leases, because the building is performing in peak range, so in those cases it wouldn't be necessary to pursue certification.

\section{Are there some buildings where you will not look to retrofit because of the difficulty in getting the building to a state where it complies with LEED standards?}

Yes. The capital required to bring some buildings up to LEED standards makes it impossible for us to get them certified. There are also issues with retrofitting existing industrial and multi-residential properties, so at this point we are only retrofitting office buildings. However, we are pursuing LEED certification for all new builds. 